Review

\title{
Aspergillosis in Wild Birds
}

\author{
Pascal Arné ${ }^{1,2, * \mathbb{D}}$, Veronica Risco-Castillo ${ }^{1,2,3} \mathbb{D}$, Grégory Jouvion ${ }^{2,3}$, Cécile Le Barzic ${ }^{1}$ and Jacques Guillot $^{2,3}{ }^{\mathbb{D}}$ \\ 1 Ecole Nationale Vétérinaire d'Alfort, Centre Hospitalier Universitaire Vétérinaire de la Faune \\ Sauvage (Chuv-FS), 94700 Maisons-Alfort, France; veronica.risco-castillo@vet-alfort.fr (V.R.-C.); \\ cecile.le-barzic@vet-alfort.fr (C.L.B.) \\ 2 Ecole Nationale Vétérinaire d'Alfort, Dynamic Research Group UPEC, EnvA, USC Anses, \\ 94700 Maisons-Alfort, France; gregory.jouvion@vet-alfort.fr (G.J.); jacques.guillot@vet-alfort.fr (J.G.) \\ 3 Ecole Nationale Vétérinaire d'Alfort, Biopôle Alfort, 94700 Maisons-Alfort, France \\ * Correspondence: pascal.arne@vet-alfort.fr; Tel.: +33-(0)143967073
}

check for updates

Citation: Arné, P.; Risco-Castillo, V.; Jouvion, G.; Le Barzic, C.; Guillot, J. Aspergillosis in Wild Birds. J. Fungi 2021, 7, 241. https://doi.org/ $10.3390 /$ jof7030241

Academic Editor: Ronen Ben-Ami

Received: 14 December 2020

Accepted: 19 March 2021

Published: 23 March 2021

Publisher's Note: MDPI stays neutral with regard to jurisdictional claims in published maps and institutional affiliations.

Copyright: (c) 2021 by the authors. Licensee MDPI, Basel, Switzerland. This article is an open access article distributed under the terms and conditions of the Creative Commons Attribution (CC BY) license (https:// creativecommons.org/licenses/by/ $4.0 /)$.

\begin{abstract}
The ubiquitous fungi belonging to the genus Aspergillus are able to proliferate in a large number of environments on organic substrates. The spores of these opportunistic pathogens, when inhaled, can cause serious and often fatal infections in a wide variety of captive and free-roaming wild birds. The relative importance of innate immunity and the level of exposure in the development of the disease can vary considerably between avian species and epidemiological situations. Given the low efficacy of therapeutic treatments, it is essential that breeders or avian practitioners know the conditions that favor the emergence of Aspergillosis in order to put adequate preventive measures in place.
\end{abstract}

Keywords: aspergillosis; wildlife; bird; Aspergillus

\section{Introduction}

Aspergillosis holds a very special place in veterinary and human medicine, because it is the main type of mycosis affecting birds and mammals, including human beings [1]. The Aves class is particularly concerned, due to [2-4]. The great diversity of species susceptible to this infection, including domestic and wild animals living in captivity or in natural environments; the omnipresence of the Aspergillus fungi in varied indoor and outdoor environments on all continents except Antarctica; the ability of this opportunistic mold to grow efficiently in its ecological niche and in birds following inhalation of its spores; the severity of the infections observed, which can result in a high mortality rate; the fact that, despite the relatively large number of case reports and amount of experimental data, particularly those obtained from poultry species, the pathogenesis of avian aspergillosis is still poorly understood [2,5].

Historically, the birds' contribution to our scientific knowledge of fungal diseases in animals is far from negligible (Table 1). Since the first reports in the early 1800s of a "mold or blue mucor" in a greater scaup (Aythya marila) by Montague and in an Eurasian jay (Garrulus glandarius) by Mayer and Emmet, many observations based on either fungal microscopic morphology or descriptions of lesions have been made on specimens of various avian species. Bronchi, lungs, air sacs, and, secondarily, bones are the most affected organs. Rayer and Montagne identified A. candidus from the air sacs of a bullfinch (Pyrrhula pyrrhula) and recognized, for the first time, the association of Aspergillus fungi with typical lesions. Following the identification of other Aspergillus species (Table 1), the first description of A. fumigatus occurred as a filamentous fungus exhibiting a "smoky grey color" in a wet mount. It was isolated in the bronchi and air sacs of a great bustard (Otis tarda) from the zoological park of Frankfurt [6,7]. 
Table 1. First descriptions of mycotic diseases in birds (Urbain and Guillot, 1938).

\begin{tabular}{|c|c|c|}
\hline Year of Notification & Species & Description \\
\hline 1813 & Scaup duck & "Mold or blue mucor" within the air sac \\
\hline 1815 & Eurasian Jay & $\begin{array}{l}\text { Parasitic thallus in air sacs, bronchi and } \\
\text { lungs }\end{array}$ \\
\hline 1816 & Mute swan & Green mold in the aerial cavities \\
\hline 1826 & Stork & $\begin{array}{l}\text { Mold lining the internal face of air sacs and } \\
\text { within long bones }\end{array}$ \\
\hline 1827 & Raven & Mold in the lungs \\
\hline 1833 & Flamingo & Mold in the pulmonary cavities \\
\hline 1841 & Eider & $\begin{array}{l}\text { A fungus in air sacs, bronchi, basin and } \\
\text { wing bones; later identified as "Aspergillus } \\
\text { glaucus" by Robin }\end{array}$ \\
\hline 1841 & Parakeet & Mycotic lesions in the lungs \\
\hline 1842 & Falcon/Owl & Mycotic lesions in the bronchi and air sacs \\
\hline 1842 & $\begin{array}{l}\text { Goose/Cormorant/Penguin } \\
\text { or Razorbill }\end{array}$ & Mycotic lesions \\
\hline 1842 & Bullfinch & $\begin{array}{l}\text { White mold ("Aspergillus candidus") in the } \\
\text { air sacs }\end{array}$ \\
\hline 1848 & Golden plover & $\begin{array}{l}\text { Mold in the air sacs later identified as } \\
\text { "Aspergillus glaucus" by Robin (1853) }\end{array}$ \\
\hline 1853 & Gull/Pheasant & $\begin{array}{l}\text { "Aspergillus nigrescens" found in the lungs } \\
\text { and the air sacs }\end{array}$ \\
\hline 1857 & Golden eagle/Ostrich & Mycelium in the airways \\
\hline 1866 & Parrot & Mold in the lungs \\
\hline 1866 & Loon & Mold in the lungs \\
\hline 1871 & Goshawk & Mold in the air sacs \\
\hline 1873 & Duck & Mold in the airways \\
\hline 1875 & Flamingo & "Aspergillus dubius" in the airways \\
\hline 1875 & Great bustard & $\begin{array}{l}\text { "Aspergillus fumigatus" in the lungs and air } \\
\text { sacs }\end{array}$ \\
\hline 1880 & Cardinal/Finches/Parrots & Aspergillosis \\
\hline 1883 & Parrot & $\begin{array}{l}\text { "Aspergillus glaucus" in the lungs and } \\
\text { bronchi }\end{array}$ \\
\hline 1883 & Flamingos & Aspergillosis \\
\hline 1885 & Ostrich & $\begin{array}{l}\text { "Aspergillus fumigatus" in the lungs and air } \\
\text { sacs }\end{array}$ \\
\hline 1887 & Swan & Aspergillosis \\
\hline 1887 & Pheasant & Aspergillosis \\
\hline 1890 & Ducks & Aspergillosis \\
\hline 1891 & Canari & "Aspergillus aviarius" in the coastal pleura \\
\hline 1894 & Swan & Aspergillosis \\
\hline
\end{tabular}

In young birds, the disease referred to as "brooder pneumonia" is the most commonly diagnosed infection in nestlings around the time of hatching. Other synonyms for avian aspergillosis include fungal or mycotic pneumonia, pneumomycosis, bronchomycosis, and colloquialisms such as "asper" and "air sac" [3].

The objective of this review was to synthesize current knowledge related to aspergillosis in wild avifauna and pet or game birds that could be useful to all those involved in the management of these kinds of animals (veterinarians, zookeepers, pet owners, conservation program managers, wildlife rehabilitators).

\section{Etiology and Ecology}

Only a small percentage of the approximately 340 accepted Aspergillus species are implicated in the development of avian aspergillosis [8]. Aspergillus fumigatus is by far the most prevalent species, representing up to $95 \%$ of cases, in both wild and domestic avifauna [3,9]. Isolation of $A$. flavus is less common and has been described in falcons [10,11], parrots [12], and a royal tern Thalasseus maximus [13]. The species A. niger 
has been isolated from sick ostriches (Struthio camelus) [14], falcons [10,15,16], a Eurasian eagle owl (Bubo bubo) [17], and African grey parrots (Psittacus erithacus) [18]. The species A. terreus $[16,19,20]$, A. versicolor $[21,22]$, A. oryzae $[23,24]$, A. nidulans [25,26], A. amstelodami, $A$. glaucus, and $A$. nigrescens [27] have been unfrequently reported in diseased birds. Mixed infections with $A$. flavus and A. niger, A. fumigatus and A. niger, and A. fumigatus and $A$. oryae, have been described in captive ostriches, falcons, and parrots, respectively $[10,23,28]$. Concomitant infections of the anterior parts of the eye in lovebirds [29] and of the lungs in white storks [30] were found to result from the association of Aspergillus sp. and Candida albicans with different zygomycetes. Although cryptic Aspergillus species may account for 10 to $14 \%$ of all clinical strains in human patients [31,32], data remain scarce in the veterinary field, and related studies have used relatively small samples. By sequencing the $\beta$-tubulin gene (benA), Vedova et al. [33] identified A. sydowii for the first time in a Swinhoe's pheasant (Lophura swinhoii). Using the same target, Talbot et al. [26] reported the new species $A$. restrictus among 26 avian clinical isolates obtained from a Java finch with disseminated invasive aspergillosis. A. allahabadii, an unknown species in birds, was cultured from the air sac of a cormorant used for traditional fishing and finally identified by the partial ben $A$ gene and ITS sequencing [34]. Molecular characterization (partial ben $A$ and cam $A$ genes sequencing) of two Aspergillus section Fumigati and one Aspergillus section Flavi [35] isolated from the black-browed albatross (Thalassarche melanophris) conclusively showed the presence of the two first isolates (A. fumigatus stricto sensu) but not the last one (A. flavus/oryzae lineage). The same team [36] identified A. fumigatus ss from lesions of three other free-ranging aquatic birds: the white-chinned petrel (Procellaria aequinoctialis), the neotropical cormorant (Nannopterum brasilianus), and the brown-hooded gull (Chroicocephalus maculipennis). Following the amplification of the $\beta$-tubulin and rodlet $A$ (rodA) genes, the 53 isolates tested by Spanamberg et al. [37] were confirmed as being A. fumigatus stricto sensu. No cryptic species from the Fumigati section were detected among 43 clinical and 34 environmental "Aspergillus fumigatus" samples in Californian rehabilitation centers using $\beta$-tubulin and camA gene sequencing [38]. The screening of 159 independent isolates from Germany by cam $A$ sequencing led to similar conclusions [39]. Those results support the preponderant role of $A$. fumigatus stricto sensu in the development of avian aspergillosis.

Indirect enzyme-linked immunosorbent assay (ELISA) tests on penguins have shown a seropositivity rate of $94 \%$ in a captive population, with an average of $60 \%$ of birds from wild colonies producing anti-Aspergillus spp. IgGs [40,41]. As evidenced by air samples, a fungal load is regularly detected in outdoor $[42,43]$ or indoor environments where birds may be found. Such observations have been done in wildlife rehabilitation centers $[43,44]$ and zoological aviaries [45-50] sheltering various species. Air contamination levels and the mycobiota composition are characterized by dynamic or cyclic variations [45-47,49]. These fluctuations may be related to season, environmental management, or to the presence of natural soil, plants, or litter [45,48]. A strong correlation between litter fungal contamination and aerial mycobiota in poultry houses corroborates the aerosolization of fungi found in litter and indicates that organic bedding may constitute the main reservoir of indoor contamination [51,52]. Aspergillus fungi may also be found in water and dust $[43,53]$. It is noteworthy that nests of wetland birds or nest-boxes of passerines can provide reservoirs of pathogenic fungi like A. fumigatus or A. flavus with up to 650 colonyforming units (CFU)/g of dry mass of the nest material [54,55]. A. fumigatus has been isolated on the feathers of 30\% [56] of free-living house sparrows (Passer domesticus) and on 6 to 13\% of pharyngeal/tracheal swabs sampled from captured pink-footed geese (Anser brachyrhynchus), Canada geese (Branta canadensis), or herring gulls (Larus argentatus) that presented as healthy carriers [57]. Positive tracheal samples from seabirds undergoing rehabilitation [43] or trapped hatchlings to second-year goshawks (Accipiter gentilis) were not rare and might indicate either exposure to the fungus or true sickness [19]. 


\section{Geographic Distribution and Seasonality}

With the exception of Antarctica, aspergillosis in wild avifauna has been reported on all continents [2]. By testing eight populations of four different Spheniscidae species for plasma Aspergillus IgG by ELISA, Graczyck and Cockrem [40] observed a latitude-related decrease of antibody seroprevalence, which seemed to reflect a decrease in the exposure of subantarctical to antarctical penguins to Aspergillus spp.

Most Aspergillosis outbreaks in North-American waterfowl population happen in fall or early winter, although individual cases can occur at any time (Figure 1) [58-63].

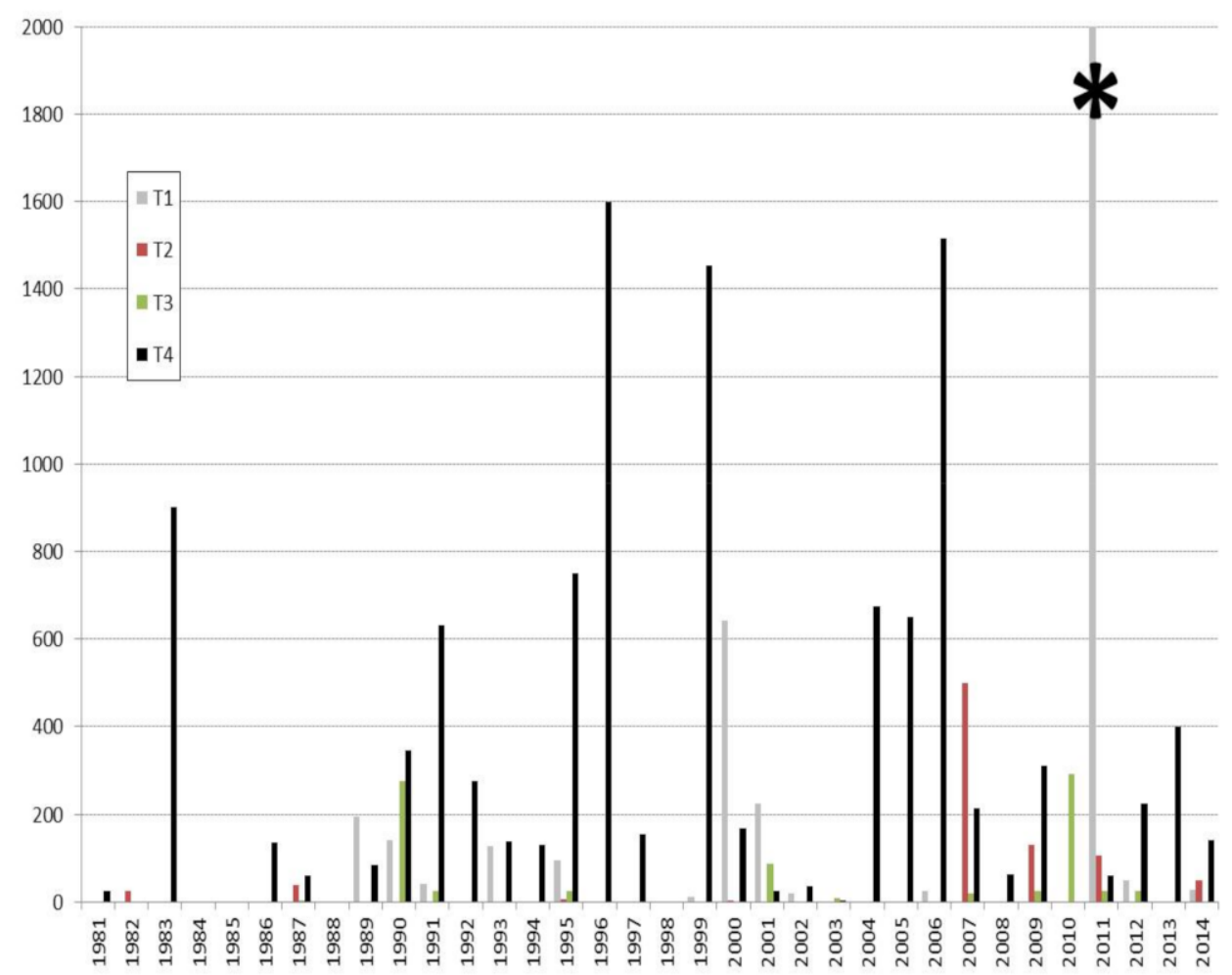

Figure 1. Quarterly die-off reports attributed to Aspergillosis in North-American avifauna. (USGS 1981-2014). T1: January to March; T2: April to June; T3: July to September; T4: October to December. * To improve the clarity of the diagram, an episode that occurred in 2011 associated with a very high mortality rate (7000 dead) is not represented in full.

This apparent seasonality may result from how local climatic conditions and fungal ecology interplay or integrate a bird's intrinsic factors, such a particular level of susceptibility at that moment of the year. Ambient temperatures and humidity play important roles in the lifecycles of fungi and the level of a bird's exposure to fungal spores, as can be seen inside poultry houses. Aspergillus fungi multiply during the wet period, producing abundant xerophilic spores which are then dispersed into the atmosphere when conditions become dry $[5,64]$. Higher morbidity and mortality rates have thus been observed in red-vented cockatoos (Cacatua haematuropygia) during the monsoon season [65].

As summarized in Figure 2, mallards, which appear to be highly susceptible to Aspergillosis may resort to rotting agricultural waste during inclement weather. Weakened by forced displacements in search for food, they may land on contaminated crops. The timing and locations of these few-days lasting outbreaks are highly suggestive of a common source of conidia and exposure within a limited time frame [27], as has been reported in poultry [66]. 


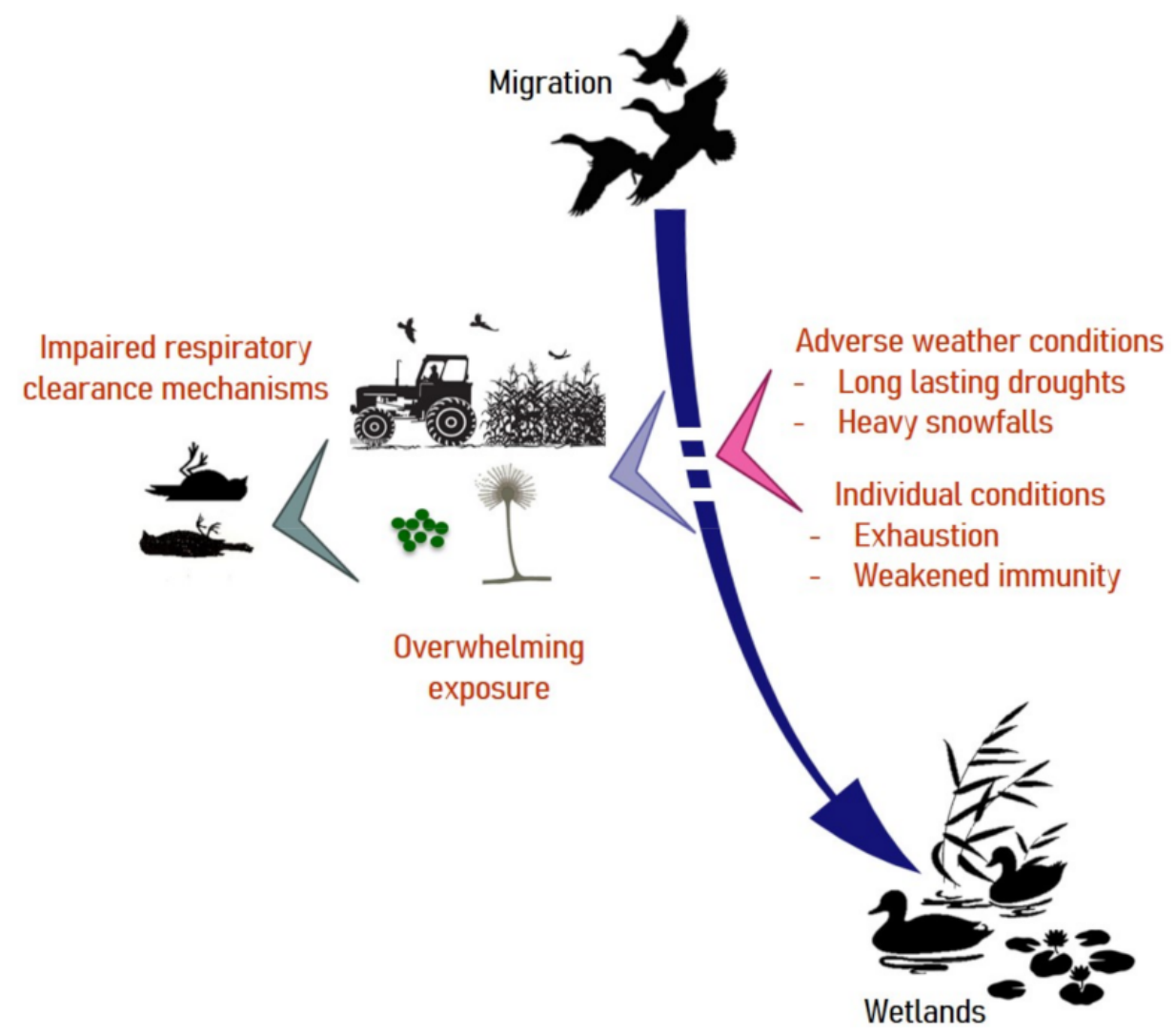

Figure 2. Risk factors associated with aspergillosis in migratory birds. Under usual climatic conditions, waterfowl exploit wetlands for food. Weather disturbances can force birds to take refuge on cultivated lands and feed on crop residues that are sometimes heavily contaminated by molds. Under such circumstances, exhausted individuals may suffer from airway clearance dysfunction and develop aspergillosis with a fatal outcome.

\section{Host Range and Impact}

Data on the frequency of aspergillosis development in wild birds is still fragmentary and may be partially biased by studies targeting specific birds or particular geographical areas. Scientific data relative to free-ranging or captive wild birds gather descriptions of sporadic cases, outbreaks and results obtained [67] during active or passive surveillance operations $[2,68]$. When die-offs occur, a highly variable fraction of carcasses or moribund birds is generally submitted to post-mortem extensive investigations. Furthermore, means engaged to establish the final diagnostic are sometimes limited to the observation of gross lesions [67] and sometimes histopathology [69-71] or based on phenotypical or polyphasic characterization of the isolated fungi $[30,35]$. Therefore, evaluations of the prevalence of aspergillosis may be overestimated and should instead refer to a "mycotic disease" when conclusions result solely from the observation of "typical lesions" [30,72].

A compilation of epizootics or mortality surveys in wild birds has been published by Converse [2]. Species that are mostly represented belong to the following taxonomic orders: Anseriformes (swans, geese and ducks), Accipitriformes (eagles and hawks), Charadriiformes (shorebirds and gulls), Passeriformes (singing birds), and Galliformes (fowls, quails and pheasants). In North America, aspergillosis is considered a common disease in waterfowl, gulls, and crows and occasionally in other songbirds and upland gamebirds [27]. Early publications mentioned the role of aspergillosis in the death of 180 wood ducks (Aix sponsa) in Illinois [58], 170 [60], 270 [62] and more than 1500 [73] mallards (Anas platyrhynchos) in three distinct episodes, as well as 2000 Canada geese (Branta canadensis) in Missouri [59] and 1000 to 1500 common crows (Corvus brachyrhynchos) in Nebraska [61]. Periodic reports published by the National Wildlife Health Laboratory of the United States Geological Survey indicate that aspergillosis is regularly associated 
with rapid die-offs among North American avifauna [74]. Mortality rates oscillate between tens, hundreds, and sometimes thousands of casualties (Figure 1). Dead and moribund birds belonging to one or several species are often found in direct proximity to moldy grain sources or rotten ensilages [58,73,74]. Waterfowl (mallards, geese) and gulls (Herring gulls) are the most commonly affected species, although their flocking behaviour and size may increase the likelihood of outbreak detection [74]. A Spanish serological survey detected the highest percentages (1.7 to 3.1\%) of positive birds in grey herons (Ardea cinerea), mallards, and coots (Fulica atra) living in the Guadalquivir marshes [75]. Aspergillus antibodies and antigens were detected in $9-50 \%$ and $27-31 \%$ of nocturnal heron chicks (Nycticorax nycticorax) belonging to distinct populations of New York Harbor estuary, respectively [76].

In the framework of mortality studies, systematic postmortem evaluations have been made in different targeted wild species, either emblematic or those proposed as potential indicators of aquatic health, such as swans or loons. Close inspection of a series of carcasses collected during pluri-annual surveys allowed a better appreciation of the impact of "aspergillosis" on avifauna (Table 2). This fungal disease was recognized as the primary cause of death for 6 to 23\% common loons [72,77-79] and 4 to 21\% swans [67,69,71,80]. During a two-year study on morbidity and mortality in a Wildlife refuge in New York [81], aspergillosis was diagnosed in 31\% of necropsied birds, mostly herring gulls. Olias et al. [30] examined 101 dead white stork chicks coming from 10 different German regions and found 45 cases of invasive fungal pneumonia, including 22 that were directly attributable to A. fumigatus. Quite similar aspergillosis-related rates of mortality (Table 2) were found for the Eurasian crane [82] and the threatened Whooping crane [70]. A retrospective analysis of aquatic bird mortality events in the US between 1971 and 2005 revealed that fungal causes, mainly due to Aspergillus fungi, accounted for $7 \%$ of mortalities attributed to infectious diseases [76].

Occasional reports of mortality have involved conservation-dependent or critically endangered species like California condors (Gymnogyps californius) (Rideout et al. 2012), Hawaiian geese (Branta sandvicensis) [83], brown kiwis (Apteryx mantelli) [48], helmeted honeyeaters (Lichenostomus melanops cassidix) [84], and yellowheads (Mohoua ochrocephala) [85]. Recently, aspergillosis killed seven kakapo parrots (Strigops habroptila), a species that has fewer than 150 fully grown birds left in the world [86]. Aspergillosis is a potentially important cause of failure of conservation and translocation programs of avian species, as highlighted by the example of the very rare New-Zealand endemic yellowhead [85] and stichbird (Notiomystis cincta). Aspergillosis was identified as the cause of the death in 11/31 free-ranging stichbirds during a 15-year period [87], in 6/9 adults between 1995 and 1997 in another location [88] and has driven the removal of a released population from their new environment due to excessive mortality [89].

While Anseriforms appear to be highly susceptible to the disease in both free-living and captive conditions [64,90-92], wide variations of prevalence do exist for other avian orders. Several case reports refer to sporadic aspergillosis in free-ranging birds of prey [19,93-98], but this mycosis is less often diagnosed in this category in comparison with captive or recently-captured free-ranging raptors, for which it is the most important non-traumatic pathology $[15,99,100]$. Many descriptions of cases concern various species of captive parrots [12,23,65,101-107]. The high frequency of reports on Accipitriformes, Falconiformes, and Psittaciformes is probably due, in part, to their popularity as appreciated pets or falconry birds. As underlined by the scientific literature, aspergillosis is a major concern for veterinarians and zookeepers in populations of penguins under human management, but it is rarely observed in free-ranging populations [108]. 
Table 2. Prevalence of aspergillosis in mortality surveys of different birds.

\begin{tabular}{|c|c|c|c|c|c|c|}
\hline Species & Period & Location & Status $^{a}$ & $\begin{array}{l}\text { \% of Aspergillosis } \\
\text { (Nb Cases/Total) }\end{array}$ & Diagnosis ${ }^{b}$ & Reference \\
\hline \multirow{6}{*}{ Common loon (Gavia immer) } & 1970-1975 & USA & $\mathrm{F}$ & $18 \%(34 / 190)$ & $\mathrm{G} / \mathrm{C}$ & [109] \\
\hline & $1976-1991$ & USA & $\mathrm{F}$ & $6 \%(13 / 222)$ & $\mathrm{G} / \mathrm{C} / \mathrm{H}$ & [77] \\
\hline & 1970-1994 & USA & $\mathrm{F}$ & $7 \%(31 / 434)$ & $\mathrm{G} / \mathrm{C} / \mathrm{H}$ & [110] \\
\hline & 1992-1995 & Canada & $\mathrm{F}$ & $16 \%(5 / 31)$ & $\mathrm{G} / \mathrm{D} / \mathrm{H}$ & [79] \\
\hline & 1979-1999 & USA & $\mathrm{F}$ & $31 \%(33 / 105)$ & Uns. & [78] \\
\hline & 1987-2000 & USA & $\mathrm{F}$ & $3 \%(14 / 522)$ & $\mathrm{G} / \mathrm{H}$ & [72] \\
\hline Mute swan (Cygnus olor) & 1996 & $\underline{\mathrm{UK}}$ & $\mathrm{F}$ & $14 \%(2 / 14)$ & $\mathrm{G} / \mathrm{H}$ & [71] \\
\hline Bewick's swan (Cygnus bewickii) & \multirow{3}{*}{ 1951-1989 } & \multirow{3}{*}{ UK } & \multirow{3}{*}{$\mathrm{F}$} & $5 \%(7 / 150)$ & \multirow{3}{*}{$\mathrm{G} / \mathrm{H}$} & \multirow{3}{*}{ [69] } \\
\hline Mute swan (Cygnus olor) & & & & $4 \%(8 / 183)$ & & \\
\hline Whooper swan (Cygnus cygnus) & & & & $4 \%(1 / 23)$ & & \\
\hline Trumpeter swan (Cygnus buccinator) & \multirow{2}{*}{ 1986-1992 } & \multirow{2}{*}{ USA } & \multirow{2}{*}{$\mathrm{F}$} & $21 \%(18 / 115)$ & \multirow{2}{*}{ G } & \multirow{2}{*}{ [67] } \\
\hline Tundra swan (Cygnus columbianus) & & & & $10 \%(2 / 21)$ & & \\
\hline Trumpeter swan (Cygnus buccinator) & \multirow{2}{*}{ 2000-2002 } & \multirow{2}{*}{ USA } & \multirow{2}{*}{$\mathrm{F}$} & $17 \%(62 / 365)$ & \multirow{2}{*}{$\mathrm{G} / \mathrm{D}$} & \multirow{2}{*}{ [80] } \\
\hline Tundra swan (Cygnus columbianus) & & & & $5 \%(2 / 35)$ & & \\
\hline Seabirds (Guillemot Uria aalge; & \multirow{4}{*}{ 1992-1995 } & \multirow{4}{*}{ Belgium } & \multirow{4}{*}{$\mathrm{F}$} & \multirow{4}{*}{$2.9 \%(6 / 241)$} & \multirow{4}{*}{$\mathrm{G} / \mathrm{H}$} & \multirow{4}{*}{ [111] } \\
\hline $\begin{array}{l}\text { Razorbill Alca torda; Herring gull } \\
\text { Larus argentatus: Kittiwake Rissa }\end{array}$ & & & & & & \\
\hline $\begin{array}{l}\text { Larus argentatus; Kittiwake Rissa } \\
\text { tridactyla; Oystercatcher Haematopus }\end{array}$ & & & & & & \\
\hline ostralegus, among others) & & & & & & \\
\hline $\begin{array}{c}\text { Herring gulls (Larus argentatus), } \\
\text { other gulls }\end{array}$ & 1981-1982 & USA & $\mathrm{F}$ & $31 \%(50 / 161)$ & $\mathrm{G} / \mathrm{C} / \mathrm{H}$ & [81] \\
\hline White stork (Ciconia ciconia) & $2007-2008$ & Germany & $\mathrm{F}$ & $28 \%(22 / 101)$ & $\begin{array}{c}\mathrm{G} / \mathrm{C} / \mathrm{H} / \mathrm{S} \\
(\mathrm{ITS}-1)\end{array}$ & {$[30]$} \\
\hline Eurasian cranes (Grus grus) & 1998-2008 & Germany & $\mathrm{F}$ & $4 \%(7 / 143)$ & $\mathrm{G} / \mathrm{C} / \mathrm{H}$ & [82] \\
\hline Whooping crane (Grus americana) & 1982-1995 & USA & $\mathrm{C}$ & $7 \%(7 / 103)$ & $\mathrm{G} / \mathrm{H}$ & [70] \\
\hline $\begin{array}{c}\text { Bewick's swan Cygnus bewickii; } \\
\text { Whooper swan C. cygnus; Black } \\
\text { swan C. atratus; Black-necked swan } \\
\text { C. melanocophyrus; Trumpeter swan } \\
\text { C. buccinator; Tundra swan C. } \\
\text { columbianus }\end{array}$ & 1951-1989 & UK & $\mathrm{C}$ & $\begin{array}{c}6.6 \% \text { (adults) } \\
5 \% \text { (juveniles) } \\
2.6 \% \text { (downies) }\end{array}$ & $\mathrm{G} / \mathrm{H}$ & [112] \\
\hline $\begin{array}{c}\text { Seaducks (European Eider Somateria } \\
\text { mollissima; Scoters Melanitta; } \\
\text { Sawbills Mergus; Goldeneyes } \\
\text { Histrionicus, Clangula, Bucephala) }\end{array}$ & 1959-1976 & USA & $\mathrm{C}$ & $\begin{array}{l}17 \% \text { (adults) } \\
31 \% \text { (juveniles) } \\
27 \% \text { (downies) }\end{array}$ & Uns. & [113] \\
\hline $\begin{array}{l}\text { Shelducks (Tadorna sp.) } \\
\text { Sheldgeese (Cyanochen sp., } \\
\text { Chloephaga sp.) }\end{array}$ & 1959-1976 & USA & $\mathrm{C}$ & $\begin{array}{c}16 \% \text { (adults) } \\
5 \% \text { (juveniles) } \\
25 \% \text { (adults) } \\
33 \% \text { (juveniles) } \\
6 \% \text { (downies) }\end{array}$ & Uns. & [113] \\
\hline $\begin{array}{l}\text { Perching ducks (Wood duck Aix } \\
\text { sponsa; Hartlaub's duck Pteronetta } \\
\text { hartlaubii, among others) }\end{array}$ & 1959-1980 & USA & C & $\begin{array}{c}7.5 \% \text { (adults) } \\
8.5 \% \text { (juveniles) }\end{array}$ & Uns. & [91] \\
\hline $\begin{array}{l}\text { Stiff-tailed ducks (Ruddy ducks } \\
\text { Oxyura sp.; Musk ducks Biziura sp.; } \\
\text { Black-headed ducks Heteronetta sp.; } \\
\text { White-backed ducks Thalassornis sp.) }\end{array}$ & 1959-1980 & USA & C & $\begin{array}{c}2 \% \text { (adults) } \\
14 \% \text { (juveniles) }\end{array}$ & Uns. & [114] \\
\hline
\end{tabular}


Table 2. Cont.

\begin{tabular}{|c|c|c|c|c|c|c|}
\hline Species & Period & Location & Status $^{a}$ & $\begin{array}{l}\text { \% of Aspergillosis } \\
\text { (Nb Cases/Total) }\end{array}$ & Diagnosis $^{b}$ & Reference \\
\hline $\begin{array}{l}\text { Northern geese (Canada geese } \\
\text { Branta canadensis; Lesser white-front } \\
\text { geese Anser erythropus ... ) }\end{array}$ & 1959-1980 & USA & $\mathrm{C}$ & $\begin{array}{c}4 \% \text { (adults) } \\
15 \% \text { (juveniles) }\end{array}$ & Uns. & [92] \\
\hline $\begin{array}{l}\text { Falcons (saker falcons Falco cherrug; } \\
\text { peregrine falcons F. peregrinus ... ) }\end{array}$ & 1998-2001 & $\begin{array}{l}\text { Saudi } \\
\text { Arabia }\end{array}$ & $\mathrm{C}$ & $10 \%(13 / 131)$ & $\mathrm{G} / \mathrm{C} / \mathrm{H}$ & [15] \\
\hline Gentoo penguins (Pygoscelis papua) & 1964-1988 & UK & $\mathrm{C}$ & $41 \%(128 / 314)$ & Uns. & [115] \\
\hline $\begin{array}{l}\text { Magellanic penguins } \\
\text { (Spheniscus magellanicus) }\end{array}$ & 1986 & USA & $\mathrm{C}$ & $61 \%(23 / 38)$ & $\mathrm{G} / \mathrm{H}$ & [116] \\
\hline $\begin{array}{l}\text { Magellanic penguins } \\
\text { (Spheniscus magellanicus) }\end{array}$ & 2008-2018 & USA & $\mathrm{C}$ & $27 \%(23 / 85)$ & $\mathrm{G} / \mathrm{H}$ & [117] \\
\hline $\begin{array}{l}\text { Psittacine birds (parrots, } \\
\text { macaws, cockatoos) }\end{array}$ & 1998-2017 & Canada & $\mathrm{C}$ & $1.7 \%(32 / 1850)$ & H/Uns. & [118] \\
\hline $\begin{array}{l}\text { Magellanic penguins } \\
\text { (Spheniscus magellanicus) }\end{array}$ & 2004-2005 & Brazil & $\mathrm{R}$ & $42 \%(5 / 12)$ & $\mathrm{G} / \mathrm{D} / \mathrm{C} / \mathrm{H}$ & [119] \\
\hline $\begin{array}{l}\text { Magellanic penguins } \\
\text { (Spheniscus magellanicus) }\end{array}$ & 2004-2009 & Brazil & $\mathrm{R}$ & $20 \%(66 / 327)$ & $\mathrm{G} / \mathrm{C} / \mathrm{H}$ & [120] \\
\hline $\begin{array}{l}\text { Bald eagle (Haliaeetus leucocephalus) } \\
\text { Golden eagle (Aquila chrysaetos) }\end{array}$ & 1975-2013 & USA & $\mathrm{R}$ & $\begin{array}{l}1 \%(35 / 2980) \\
1 \%(15 / 1427)\end{array}$ & Uns. & [100] \\
\hline $\begin{array}{l}\text { Black-browed Albatross } \\
\text { (Thalassarche melanophris) }\end{array}$ & 2015-2017 & Brazil & $\mathrm{R}$ & $14 \%(3 / 14)$ & $\begin{array}{c}\mathrm{G} / \mathrm{C} / \mathrm{H} / \mathrm{S} \\
(\text { ben } A, \text { calM })\end{array}$ & [35] \\
\hline
\end{tabular}

${ }^{\mathrm{a}} \mathrm{F}$ = free-ranging birds; C: permanent captivity; R: transitory captivity or rehabilitation; ${ }^{\mathrm{b}}$ based on gross lesions (G); direct fungal examination (D); fungal culture (C); histopathology (H); gene(s) sequencing (S); unspecified (Uns.).

Death by aspergillosis has been described in captive gentoo penguins [115], Magellanic penguins [29,116,119,120], Humboldt penguins (Spheniscus humboldti) [121], king penguins (Aptenodytes patagonica) [41], and African penguins (Spheniscus demersus) [122,123]. Postmortem diagnosis confirmed the implication of aspergillosis in $29 \%, 33 \%$, and $48 \%$ of serial deaths in Magellanic penguins, king penguins, and gentoo penguins, respectively $[41,115,124]$.

\section{Disease Predisposition}

In domestic birds, both field data and experimental results have clearly demonstrated a higher susceptibility of turkeys (Meleagris gallopavo) and quails (Coturnix japonica) to aspergillosis when compared to chickens, for example [125]. Furthermore, differences in susceptibility have been demonstrated between different turkey and chicken lineages following experimental inoculation of spores [3]. In wild species, empirical data claim that gyrfalcons (Falco rusticolus) and hybrids, merlins (Falco columbarius), goshawks, redtailed hawks (Buteo jamaicensis), ospreys (Pandion haliaetus), rough-legged hawks (Buteo lagopus), golden eagles and snowy owls (Nyctea scandiaca) are highly susceptible to aspergillosis $[99,126]$. Similar observations have been made for the blue-fronted amazon (Amazona aestiva), the African grey parrot, and pionus parrots (Pionus spp.) among psittacine birds [4]. When mixed groups experience aspergillosis, mortality may affect only some species. In an American aquarium, 19\% of 85 tufted penguins (Lunda cirrhata) and $30 \%$ of 20 pigeon guillemots (Cepphus columba) died, but none of the 20 rhinoceros auklets (Cerorhinca monocerata), despite being housed in the same area [127]. In Cheasapeake bay, 36 of 50 canvasbacks (Aythya valisineria) succumbed to aspergillosis, but 12 redheads (Aythya americana) and 12 scaup ducks (Aythya sp.) which belonged to the same captive flock were unaffected [90].

Souza and Degernes [80] found than male swans were twice as likely as females to have fungal disease, whereas the role of gender in susceptibility to aspergillosis has not been 
documented in raptors [126]. Cumulative data show that young animals are particularly prone to the development of aspergillosis in poultry [3] and wild birds. Young raptors, notably, immature red-tailed hawks, seem to be more susceptible between 2 to 4 months of age $[99,126]$. Aspergillosis is prominent in captive downies and juveniles (Table 2) of different waterfowl species (northern geese and perching ducks) and in rehabilitated juvenile penguins in comparison to adults $[91,92,120]$. Immature loons were found to be significantly more likely to be affected than breeding or wintering adults [72]. A similar higher incidence among juveniles has been noted in free-ranging swans [69] that has been associated with the occurrence of more severe lesions than in adults or sub-adults [80]. During a 2-year survey, $96 \%$ of the herring gulls diagnosed as having aspergillosis were sub-adult birds [81].

There are multiple external factors implicated in causality. Accidental ingestion of heavy metals, particularly lead, has been associated with aspergillosis in loons [78] and swans [71]. However, Souza and Degernes [80] established that lead exposure is not a risk factor for the development of the mycosis, which remains mild in affected swans. These observations indicate that rapid death following primary acute lead intoxication might prevent the development of severe fungal lesions. Two migrating Eurasian black vultures (Aegypius monachus) were found to be suffering from aspergillosis and acute carbofuran insecticide poisoning (Jung et al. 2009). Other non-infectious conditions associated with aspergillosis in wild avifauna include trauma, gunshots, extreme wear to flight feathers, oiling, emaciation, and exhaustion consecutive to migration [19,59,72,78,97,109]. Mixed infections are not uncommon in free-living and captive wild birds. They do not always indicate whether aspergillosis is a primary or secondary infection. Reported intercurrent diseases include tuberculosis in birds of prey and in an egret Egretta thula $[25,94,128]$, salmonellosis in loons [109], polymicrobial infection in Cape vultures (Gyps coprotheres) [129], botulism in shore birds [81], psittacine beak and feather disease and Budgerigar fledging disease in an African grey parrot [130], Eastern equine encephalitis in African penguins [122], hepatitis E virus infection in Himalayan griffons (Gyps himalayensis) [21], Pox virus infection in a royal tern (Thalasseus maximus) [13], avian malaria in Magellanic penguins [116,131], helminthosis in a black-eared milan (Milvus migrans) [98], a blue jay (Cyanocitta cristata) [132] or a herring gull [133], tracheal trematodosis in swans [71], sarcocystosis in parrots [104], trichomonosis in raptors [134,135], and amebiasis in great blue turacos (Corythaeola cistata) [136]. The use of broad-spectrum antibiotics and immunosuppressive therapies (corticosteroids) can stimulate the occurrence of fungal pathogens in debilitated birds [23,107,137].

Concomitant primary pathogenic agents and/or diseases were identified in 64 of 94 Aspergillus-positive cases in captive falcons. When compared with a control group of 2000 disease-free falcons, Babesia shortii, Mannheimia haemolytica, Escherichia coli, and Falcon herpesvirus infection, but not Trichomonas infection, appeared to be suitable candidates as predisposing factors for aspergillosis [10].

As emphasized by observations in birds of prey and penguins, captivity itself may be a major contributor to the emergence of aspergillosis, especially when deleterious conditions such as overcrowding, poor ventilation, thermal discomfort, or a high level of exposure to respiratory irritants (ammoniac, dust) occur $[99,102,107,126]$. This is even truer in the case of animals recently captured in the wild. Increased incidences of fungal infections have been registered for parrots, raptors, and penguins coming into permanent or transitory captivity $[23,116,135]$. Aspergillosis was diagnosed in 31 out of 42 Philippine red-vented cockatoos and 55 out of 179 houbara bustards (Chlamydotis undulata macqueeni) after they were trapped in the framework of legal or illegal trades [65,138]. In companion animals, hypovitaminosis A [101], participation in a bird song contest [37], transportation [139], intensive falconry training [126], or a change of ownership [99] have been identified as potential stressors eliciting aspergillosis.

Aspergillosis is a common and particularly feared complication of oil spills in rehabilitation centers with high mortality rates occurring on either oiled and non-oiled 
common murres (Uria aalge), razorbills (Alca torda), common loons, New Zealand dotterels (Charadrius obscurus aquilonius), and Magellanic penguins [120,140-143].

\section{Pathogenesis}

Aspergillosis typically occurs after the inhalation of the ubiquitously available spores, but localized infections of the eye or the skin are possible $[29,144,145]$. Several forms are classically recognized. Acute disease may occur following exposure to an overwhelming number of spores from a point source. More chronic forms are slowly progressing infections that affect birds showing some degree of immunodeficiency and may result from the regular inhalation of spores. Understanding the relative contributions of the level of exposure and the transient susceptibility of the host in the initiation of infection remains a challenge [3].

The question surrounding the infectious dose is still fundamental. Experimental models of acute aspergillosis indicate that unless the dose is massive $\left(10^{6}\right.$ to $10^{8}$ spores / bird), exposure via different ways rarely produces disease and may affect species differently [5]. The intra-tracheal administration (IT) of $1.35 \times 10^{6}$ spores/starling (Sturnus vulgaris) induces mortality in 100\% of affected individuals in 6 days [146]. Inoculum of $10^{7}$ (IT) and $2.10^{7}$ spores (injected into the thoracic air sac) killed 2/5 and $4 / 4$ rock pigeons (Columba livia), respectively, but none of five gyr-saker hybrid falcons (Falco rusticolus $x$ F. cherrug) submitted to a lower IT dose died [147,148]. In another experiment, all falcons (two peregrine falcons Falco peregrinus and two saker $x$ gyrfalcons) receiving $2.10^{7}$ spores IT succumbed to the infection following very rapid health deterioration [149]. A lethal dose 50 (LD50) of $12.03 \times 10^{6} /$ bird was established in Japanese quails by Chaudhari and Sadana [150]. Based on histopathological results as definitive diagnosis of experimental aspergillosis in gyr-saker hybrid falcons, Fischer et al. (2018) calculated different minimal infectious doses

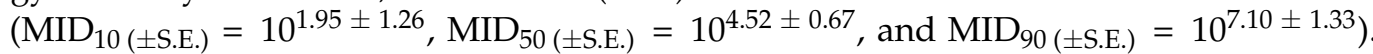
Based on $\mathrm{MID}_{10}$ and on respiratory minute ventilation, the authors extrapolated their data to determine the tolerable spore concentration in ambient air that must be inhaled over $24 \mathrm{~h}$ by a resting juvenile falcon as being $86.50 \mathrm{CFU} / \mathrm{m}^{3} / \mathrm{h}$. Air samples collected under various contexts linked to birds have highlighted the wide variability of aerial fungal loads [5,45-47,49]. Maximal indoor measurements of the airborne A. fumigatus spores concentration in a German falcon breeder center [151], three Californian rehabilitation centers and one Italian rehabilitation center all sheltering aspergillosis-diseased birds were 45, 50, and up to $525 \mathrm{CFU} / \mathrm{m}^{3}$, respectively. The difficulty in clearly correlating exposure to given fungal loads and aspergillosis occurrence combined with the variability of experimental results underline the preponderant role of spontaneous susceptibility in birds, which differs at the species, age, and even individual level. In fact, most mycoses in captive birds could be related to issues of husbandry-associated stress, rather than to the presence of specific fungal populations in the air [47].

The anatomo-physiological characteristics of the respiratory systems of birds as well as their innate immune responses may suggest that all avian species are susceptible to developing aspergillosis under favorable circumstances. Spores of A. fumigatus, when inhaled through the nares, are small enough $[9,152]$ to bypass mucociliary-dependent clearance by the upper airways and disseminate first in the posterior air sacs rather than in the cranial ones, in accordance with the gas pathway through the lungs $[153,154]$. The trachea or syrinx may be involved as well due to anatomical particularities, such as tracheal loops in swans [80] or unlaminar air-flow conditions through a narrow lumen. Air sacs are particularly prone to contamination because they have an air flow regime that favors particle deposition, no available macrophages to remove foreign items, and an epithelial surface that is nearly devoid of a mucociliary transport mechanism [155]. In this primary nidus, thermophilic spores find ideal temperature and aeration conditions to break their dormancy, germinate, and produce multicellular hyphae [53]. Mycelial development causes tissue necrosis and incites a strong host reaction than can be granulomatous and/or infiltrative, depending on the immune status of the bird [156]. It relies on a mixed inflammatory response that involves the recruitment of macrophages, multinucleated giant cells, 
and heterophils. These cells form within the lung parenchyma as characteristic granulomas around a necrotic center containing radiating hyphae which may be encapsulated by an outer layer of fibrous tissue [88] or constitute plaques lining air sac membranes or airways. In vitro, macrophages of rock pigeons demonstrate a limited capacity to kill phagocytized spores but inhibit their germination unless the spores are not too numerous. The fact that intracellular germination and subsequent cell death may occur following multiple spore ingestion may explain the limited efficiency of this first line in cases of overwhelming exposure to spores [148]. Heterophil granulocytes of the second line kill non-ingested hyphae by oxidative and non-oxidative mechanisms. When the immune response is less effective, infiltrative types of tissue reactions include exudative cellular inflammation with giant cells, macrophages, heterophils, and lymphocytes. In that case, the fungus can spread from the respiratory system via the circulatory system through pneumatized bones or by simple extension from the air sac wall to contiguous organs or cavities. Hematogenous or lymphatic dissemination of fungal elements is allowed by hyphal penetration of the lung blood vessels and by means of macrophages carrying viable spores. Under appropriate aerobic conditions, fungal asexual reproduction within air sacs is a common feature associated with plaques becoming velvety and changing color depending on the Aspergillus species involved [156].

Many species of Aspergillus are able to synthesize mycotoxins [7]. The exact role of these secondary metabolites in the development of aspergillosis remains unclear. The ergoline alkaloid fumigaclavine $\mathrm{A}$ has been shown to be produced by A. fumigatus during the course of clinical aspergillosis in the lungs of falcons (Falco sp.) [156]. In turkeys, high concentrations of gliotoxin, a mycotoxin with an immunosuppressive effect, have been detected in tissues obtained from birds with spontaneous airsacculitis [157] or in the lungs of birds experimentally inoculated with A. fumigatus [157]. Finally, turkey blood peripheral lymphocytes, when exposed to high levels of gliotoxin, either died or exhibited a lower lymphoblastogenic response [158]. This review does not address mycotoxicosis due to the ingestion of mycotoxins (aflatoxins in particular) which have already been shown to be responsible for high mortality rates in wild avifauna [159] in connection with moldy grain or contaminated feeders $[160,161]$.

Using discriminant molecular tools, a constant and very high polymorphism of Aspergillus fumigatus isolated either from the environment or internal organs of both healthy and diseased birds has been demonstrated in several studies [5,162]. However, the origin of this remarkable variability, the role of sexual reproduction in its occurrence, and its putative pathological implications remain uncertain [53]. Polyclonal infections have already been reported in captive penguins and free-ranging white stork chicks $[30,123]$.

Finally, it is still not clear why there is selective pressure for continued animal pathogenicity among fungi that are well adapted to abiotic environments.

\section{Clinical Signs}

Aspergillosis expression in birds may be reported during field outbreaks and the careful monitoring of its progression in diseased, captive birds or experimentally inoculated animals. Affected free-living birds are generally found moribund or dead. Acute aspergillosis usually presents with fairly non-specific signs such as lethargy, dullness, and ruffled feathers $[27,88]$. Loss of interest in food and anorexia are common observations, but pronounced weight loss is rather associated with chronic forms of the disease. Freeranging birds may be reluctant to escape, walk with effort, or fly due to suffering from shot injuries and are therefore caught easily [58]. Polydipsia, polyuria, wing drop, stunting, and sudden death occur regularly. All of these signs are similar to those of lead poisoning $[4,27]$. Subtle non-specific first signs observed by falconers are a decrease in preening activity, a loss of ability to engage in prey hunting and even fly, and a failure to bathe $[95,99,134]$. More characteristic is the development of progressive and severe dyspnea with gasping, accelerated open-mouth breathing, tail-bobbing, and sometimes, a non-productive cough Gurgle, rales, or wheezy sounds and a change in voice may be heard in cases of my- 
cotic tracheitis $[11,39,88,134,137,139,163]$. Central nervous system involvement causes a loss of muscular coordination, twisting of the neck, and a head held in abnormal positions $[12,27,44,89,99]$. In controlled experiments of acute aspergillosis, respiratory signs (tachypnea, dyspnea with gasping, abdominal breathing), depression, anorexia, and ruffled feathers are common in inoculated (IT) starlings, pigeons, Japanese quails, and rock pigeons. Less frequent observations include greenish urates and vomiting [146-148,164].

An unusual presentation may affect organs other than the respiratory tract. Aspergillosis rhinitis and sinusitis cause nasal discharge in parrots [102]. Abrams et al. [145] described a severe bilateral inflammation and dermatitis of the eyelids that progressively extended to the head in a falcon hybrid. Aspergillus infections of the internal chambers of the eye are not rare in parrots and cause epiphora, blepharospasm, photophobia, periorbital swelling, and corneal ulcers $[29,144]$. Abnormal limb movements and paralysis associated with spinal or perirenal lesions have been reported in game pheasants [165], a black palm cockatoo (Probosciger aterrimus) [166], and a bufflehead duckling (Bucephala albeola) [167]. Painful aspergillosis granulomas could generate feather damaging behavior and skin mutilation in parrots [168]. Aspergillus spp. is considered a secondary invader in extensive foot web necrotic lesions of unknown origin in wild swans caught for routine banding [169].

\section{Gross Lesions}

Birds that succumb to acute aspergillosis are generally in good flesh condition $[170,171]$, while wasting (pectoral muscle atrophy and negligible subcutaneous and internal fat) and dehydration are common features of chronic infection $[97,98,134,172]$. Emaciation has been correlated with the progression of the disease in common loons sheltered for rehabilitation [140]. As infection generally develops following the inhalation of spores, typical primary lesions are found in the respiratory tract and may be restricted to this area $[11,12,30,37,39,173]$. Souza and Degernes [80] qualified the infection as mild when it affected only one organ (either the trachea, the lungs or the air sacs) and as severe when at least two locations were involved. Isolated syrinx or tracheal bifurcation involvement is not rare and may be life-threatening with possible asphyxiation [174]. Internal air-flow circulation means that lungs and posterior air sacs (thoracic and abdominal pairs) are infected more often than anterior ones. The severity and the degree of development of the disease determine both the morphology and extension of macroscopic lesions along the coelomic serosa [102]. Gross lesions, either alone or in association (invasive aspergillosis) with others, have been observed in/on the brain, kidneys, liver, spleen, intestine, testis, bones, pericardium, and aorta $[13,35,36,44,88,103,128,166,167,172,175-179]$. The initial phase is characterized by hemorrhagic and edematous lesions that progress to a granulomatous type of inflammation [140]. Macroscopic lesions consist of white-yellowish unique or multiple spherical nodules ranging from miliary $(<1 \mathrm{~mm}$ in diameter) to large roughly spherical granulomas $(>40 \mathrm{~mm}$ ) involving serosae and parenchyma of one or multiple organs [44,131]. Parenchyma are either consolidated or scattered with dense granulomas. When coalescing in air sacs, these deposits, varying in size and shape, form cheesy caseous plaques covering the thickened membranes and even obstructing the entire lumina where fungal sporulation may occur, as evidenced by a grey-greenish to black cottony texture $[96,156]$.

\section{Histopathology}

Hematoxylin-eosin staining is often completed with periodic acid-Schiff and/or Grocott, Gomori's methenamine silver dyes in order to detect fungal elements in tissue sections $[156,180]$. The use of fluorescent staining with the optical brightener blankophor has proven to be a valuable tool [181].

Microscopic examination of Canada geese victims of an aspergillosis outbreak led McDougle and Vaught [59] to describe three distinct types of lung infection: acute hemorrhagic pneumonia with few cells in the airways, a subacute form associated with caseous granulomas containing giant cells and radiating mycelia, and a chronic presentation char- 
acterized by extensive loss of normal tissue architecture following granuloma formation and hepatization. Based on histopathological differences, Cacciutello et al. [156] distinguished a deep nodular form of aspergillosis in non-aerated parenchyma and a superficial diffuse form in aerated tissue [171,182], although granulomas are frequently seen in the pulmonary parenchyma $[97,140,178,181]$. The classical structure of heterophilic granulomas consists of a necrotic center containing degenerate heterophils and radially arranged fungal elements surrounded by intact heterophils and a layer of epithelioid macrophages, multinucleated giant cells, and sparser lymphocytes or plasma cells [30] (Figure 3). In chronic forms, the effective host response can result in the formation of a fibrous layer circumscribing the granuloma. An Aspergillus-linked pneumonia without any gross lesion detection has been described following a systematic histopathological investigation in white storks. These pneumonia cases were characterized by multifocal poorly circumscribed aggregates of epithelioid macrophages and multinucleated giant cells surrounding filamentous fungus structures [30]. In the lungs, the infiltrative or diffuse forms of the disease induce hyperemia, micro-hemorrhages, a loss of epithelium lining in the bronchi, and its replacement with inflammatory exudate and cells (mostly degenerated heterophils and macrophages) extending to the peripheral parenchyma and pleura. The lung structure may be consequently replaced by multiple large areas of necrosis due to the coalescence of adjacent parabronchial foci $[12,13,97,178]$. The accumulation of various fungal elements (conidiophores, spores, hyphae), inflammatory exudate, and cells in and around airways are common features $[28,44,171]$. Fungal angioinvasion results in hemorrhages, vascular thrombosis, tissue infarction, and putative dissemination of Aspergillus to distant organs $[23,172,182]$. Air sac walls are diffusely thickened by infiltrates containing fibrin, heterophils, and macrophages, whereas their surface is colonized by mycelium with occasional conidial heads $[17,98,131]$. The presence of oxalate crystals in necrotized areas is an inconstant finding $[17,23,95]$, but its frequency in avian aspergillosis could be underestimated, as demonstrated by Payne et al. [22]. More anecdotally, the ascospores, perithecia, and asci of $A$. nidulans have been documented in the lungs of an egret [25].

In several parrot species, microscopic lesions of the upper respiratory tract, possibly accompanied by malformation of the nostrils (with the presence of rhinoliths), beak, and cere, have been reported with hyphae filling the nasal cavity and paranasal sinuses, invading blood vessels, nerve bundles, turbinate cartilages, and nasal bones in severe cases $[39,102]$. In an enucleated eye of an amazon parrot, Hoppes et al. [144] described extensive, severe heterophilic, lymphoplasmacytic, and granulomatous keratitis, scleritis, and anterior uveitis. In the absence of respiratory lesions, the concentration of fungal elements in the cornea and, in less frequently, in the ocular chambers are suggestive of direct environmental contamination by contact. 

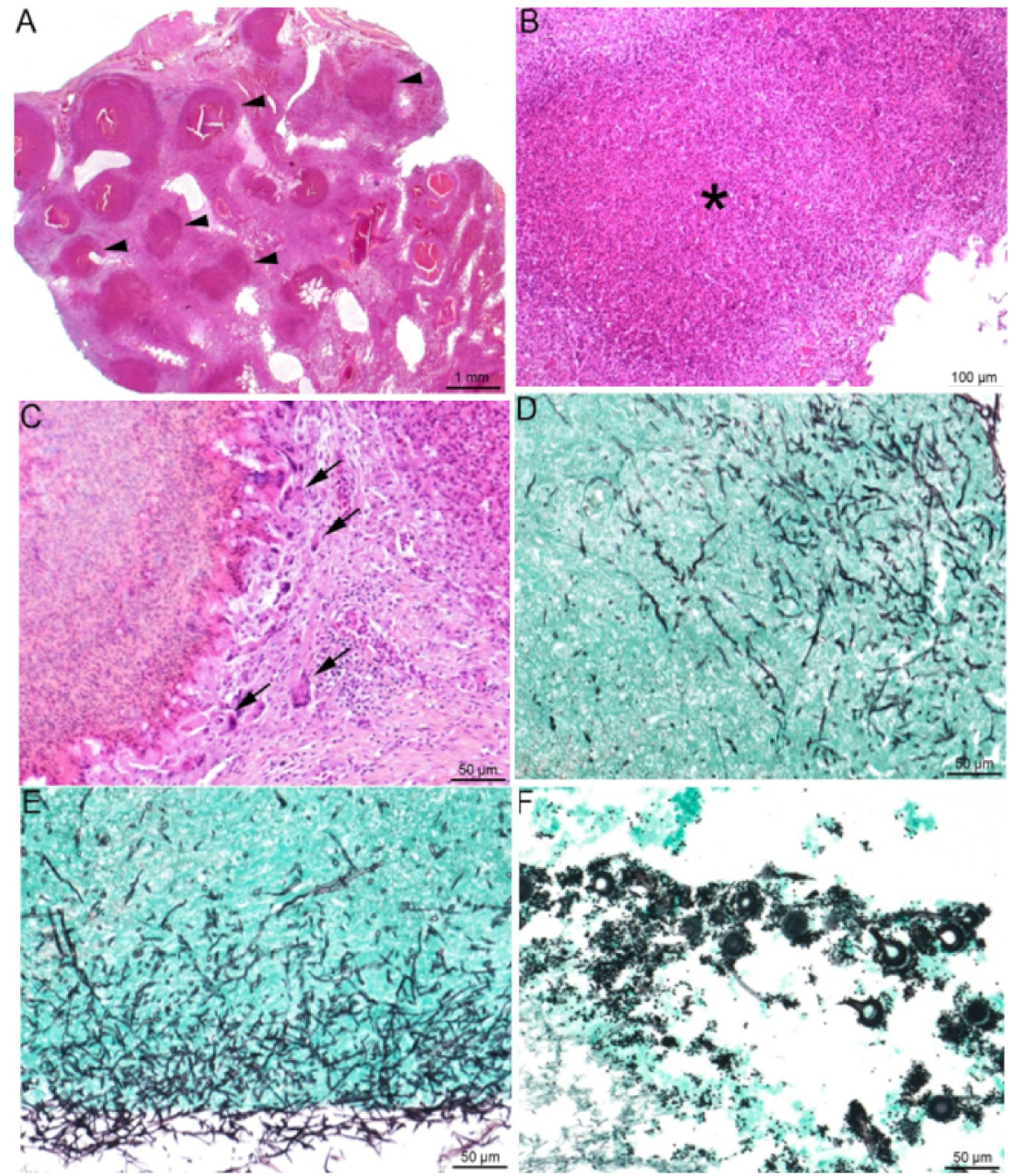

Figure 3. Lung histopathological lesions compatible with aspergillosis. (A-E) Lung of a knob-billed duck (Sarkidiornis melanotos). (A) Multifocal to coalescing heterophilic granulomas (black arrowheads), (B) displaying necrosis of heterophils and macrophages in their center ${ }^{*}$ ) and (C) a peripheral rim of giant multinucleated cells (black arrowheads). In the granulomas (D) and the lung surface (E), the presence of invading thin (3- to $12 \mu \mathrm{m}$ ), non-pigmented (hyaline), septated hyphae with homogenous acute angle branching consistent with Aspergillus spp. (F) Lung of a red-crested pochard (Netta rufina) with numerous Aspergillus spp. conidial heads. (A-C): HES staining; (D-F): Gomori Grocott staining.

\section{Diagnostics}

The recognition of aspergillosis in wild birds may be established either antemortem or postmortem $[2,183]$. Non-Aspergillus fungal species are able to produce similar lesions $[30,180]$. Furthermore, due to the ubiquitous nature of Aspergillus in the environment, positive cultivation from integument or respiratory tissues without any associated lesions may be frequent but should not be interpreted as a positive diagnosis of aspergillosis [3]. Therefore, a definitive diagnosis requires the identification of Aspergillus spp. from associated lesions [30]. Culture and isolation of the fungal agent for further characterization is considered the gold standard. In the absence of pathognomonic structures such as conidiophores, and since in vivo hyphal morphologies may overlap between Aspergillus fungi and multiple other fungi, histopathological observations of dichotomously branching hyaline 
hyphae with parallel walls on histopathological preparation may lead to false positives. In that case, immunohistochemistry with monoclonal or polyclonal antibodies is a powerful and accurate tool to identify in situ infections due to Aspergillus spp. or when mycological cultures remain negative $[21,29,180,184]$.

Classical ante mortem diagnostic procedures include blood work, serology, and imaging [185]. However, ante mortem diagnosis of avian aspergillosis is much more challenging when cytological evaluation of clinical samples is not feasible. It is also problematic because extensive involvement of the respiratory tract can be present before clinical signs are apparent. Despite the presence of non-specific clinical signs, aspergillosis should be strongly suspected when debilitated birds suffering from respiratory distress are non-responsive to antibiotic treatment and when careful history may reveal the presence of underlying environmental or immunosuppressive factors $[4,185]$.

In birds that are able to mount an appropriate immune response, blood work may reveal moderate to severe leukocytosis (20,000 to more than 100,000 cells per $\mu \mathrm{L}$ ), heterophilia with a reactive left shift (toxic changes), monocytosis, and hyperproteinemia [4]. Plasma or serum protein electrophoresis can be used to obtain an overview of inflammatory changes. Both clinical and experimental data in falcons and psittacines indicate that an increase in $\beta$-globulins, hypoalbuminemia, a decreased albumin:globulin ratio $(<0.5)$, and lower prealbumin values may be indicative of aspergillosis [105,186-190]. Desoubeaux et al. [191] combined a new biomarker with plasma protein electrophoresis in order to detect spontaneous cases of aspergillosis in a cohort of African penguins. Using 3-hydroxybutyrate, $\beta$-globulin, and $\alpha 2$-globulin measures in tandem resulted in a high level of specificity $(>90 \%)$ and a negative predictive value $(\geq 80 \%)$. The evaluation of two acute-phase proteins (haptoglobin and serum amyloid A) in falcons [190,192] and Japanese quails [193] gave contrasting results.

Two commercial ELISA kits have been used to detect two polysaccharidic components of the fungal cell wall: the galactomannan (GM) is relatively specific for Aspergillus, whereas (1-3)- $\beta$-glucan (BG) should be considered a panfungal test [194]. Different trials in various bird species showed low levels of sensitivity and poor correlations between the GM index and the disease status $[187,188,190,191,195,196]$. The BG assay appeared to be more suitable, although the results were also species-dependent with higher average concentrations seen in infected seabirds compared to raptors or companion birds [197]. PCR appears to be a very sensitive and cost-effective diagnostic tool which is still in its infancy in avian medicine. Mostly used for research purpose until recent years, PCR, generally based on $18 \mathrm{~S}$ rRNA, allows the detection and identification of Aspergillus spp. isolated from field cases $[21,30,97,123,130,198,199]$.

Serologic assays for the presence of anti-Aspergillus have been used in parrots, birds of prey, and penguins. However, the ubiquitous dispersal of Aspergillus spores and the inability of birds to mount an adequate immune response due to the animal's severe disease state have resulted in false positives and false negatives, respectively, which greatly limit the diagnostic value of serology when used alone [40,41,99,186,187,190,200-202]. In a recent experimental model of acute aspergillosis in peregrine and peregrine $\mathrm{x}$ saker falcons, Wernery et al. [149] underlined the ability of anti-Afm1p (a highly immunogenic A. fumigatus galactomannoprotein) antibodies to discriminate inoculated birds from apparently healthy falcons by ELISA.

A combination of different diagnostic tools may overcome the intrinsic limitations of each test that are inherent to the variability of the host's status and the disease severity. Hence, repeated testing can improve their levels of performance and can be used to evaluate disease progression and treatment success [201].

Radiography is part of the routine clinical examination of sick birds. However, the presence of radiologic signs indicates that birds are already in a late phase of the disease. Computer tomography and magnetic resonance imaging offer greater resolution and can highlight the invasive nature of the disease in birds. However none of these three imaging techniques can conclusively diagnose aspergillosis [203-205]. Endoscopy is an 
invasive procedure that readily enables veterinary practitioners to detect aspergillosis lesions (thickened air sac membranes, white-yellow, nodular, granulomatous, coalescing, plaque-like lesions, pigmented mold) and to collect samples (air sac lavages, biopsy, contact smears) for Aspergillus identification. Bronchoscopy is useful for the visualization of tracheal lesions and facilitates their removal [206].

\section{Treatment}

Treatment of avian aspergillosis, when possible, is not always successful because of the often advanced stage of the disease when the diagnosis is confirmed, the lack of pharmacokinetic data on antifungal drugs in most avian species, the failure of drugs to penetrate target tissues (especially encapsulated granulomatous lesions), and the frequent presence of concurrent diseases and/or immunosuppression [4,207]. Companion birds, raptors trained in falconry, and birds presented in zoos or to a lesser extent treated in wildlife rehabilitation centers can benefit from different therapeutic strategies. If a bird can tolerate anesthesia, the best way to overcome the disease is through topical therapy after surgical debridement via endoscopy of caseous material and granulomas, even in combination with early, aggressive, systemic, antifungal treatment $[208,209]$. Vacuum suction treatment proved to be effective for removing syringeal and tracheal mycotic obstructions detected by tracheoscopy in psittacines [174].

Historically, many protocols using different antifungal molecules or administration routes have been used as curative and even metaphylactic options in different species of wild birds. An oral solution of itraconazole (Fungitraxx, Floris, Vught, The Netherlands) was recently registered as the first antifungal product for ornamental birds in Europe. Given its broad antifungal spectrum and its fungicidal action on molds, voriconazole is increasingly being used to treat invasive aspergillosis in birds [207,209-212]. However, the empirical use of standard dosages to treat a great variety of bird species raises questions and underlines the need for more evidence-based data [207,209]. Recent research (Table 3) has focused on evaluating the bioavailability of the most promising molecules in different target species and more rarely on their therapeutic efficacy in experimental models of aspergillosis.

Both the formulation and the route of administration of antifungals should be carefully evaluated in targeted host species in order to reduce toxic effects and improve the long-term treatment of aspergillosis $[213,214]$. Effective management of captive birds, in particular, fragile individuals or birds at risk of immunosuppression (for example, following oil spill episodes), requires the minimization of handling stress. If subcutaneous implants of antifungal agents fail to reach targeted plasma concentrations [8,216], the nebulization of antifungal molecules could represent a promising technique that is applicable to groups of animals even prophylactically [216-218]. Some therapeutic protocols are summarized in Table 4.

In the framework of the one health context [219] and considering the limited number of drugs available to treat aspergillosis, the recent increase in antifungal resistance in human medicine should not be neglected by veterinarians and therefore should be carefully monitored [220,221]. The flight ability allows birds to travel great distances between cultivated fields that may be treated with fungicides. Consequently, birds might transfer Aspergillus isolates in this way, some of which could be resistant [222].

Using the CLSI method, the in vitro susceptibility of 59 avian A. fumigatus strains to amphotericin B, itraconazole, and voriconazole was determined. Four isolates showed acquired resistance to both itraconazole and voriconazole [223]. Twenty-two Aspergillus section Fumigati isolated from British captive penguins proved to be terbinafine- and voriconazole-sensitive, but all were resistant to itraconazole using minimum inhibitory concentrations cutoff values [224]. Investigation of antifungal susceptibility remains scarce in the field of wild avifauna and has been limited to newly identified Aspergillus species [33,34] or to a few drugs. All 18 clinical and 9 environmental $A$. fumigatus stricto sensu from a Californian rehabilitation center for seabirds were found to be sensitive to itraconazole [38]. 
Only one of 159 independent isolates from Germany was found to be azole (itraconazole and voriconazole) resistant [39]. In the framework of epidemiological surveys, more extensive screening could increase the detectability of resistant Aspergillus fumigatus isolates and even a multi-resistance pattern, as demonstrated in poultry contexts $[225,226]$.

Table 3. Bioavailability and efficacy of different antifungal agents tested experimentally in several avian species.

\begin{tabular}{|c|c|c|c|c|c|c|}
\hline $\begin{array}{c}\text { Antifungal } \\
\text { Agent }\end{array}$ & Status/Species & $\begin{array}{c}\text { Administration } \\
\text { Route }\end{array}$ & Dose & Aim & Main Conclusions & References \\
\hline $\begin{array}{l}\text { Amphotericin B } \\
\text { (Liposomal) }\end{array}$ & $\begin{array}{l}\text { Mallard ducks } \\
\text { (Healthy) }\end{array}$ & $\begin{array}{l}\text { Intratracheal } \\
\text { nebulization } \\
\text { (atomizer) }\end{array}$ & $\begin{array}{l}3 \mathrm{mg} / \mathrm{kg} \\
\text { (single) }\end{array}$ & PK & $\begin{array}{c}\text { Target dose of } 1 \mu \mathrm{g} / \mathrm{g} \text { of } \\
\text { lungs reached (up to } \\
9 \text { days) } \\
\text { No toxic changes } \\
\text { (histological } \\
\text { examination) }\end{array}$ & [217] \\
\hline $\begin{array}{c}\text { Terbinafine } \\
\text { hydrochloride }\end{array}$ & $\begin{array}{c}\text { Shelduck } \\
\text { (Tadorna tadorna) } \\
\text { (Healthy) }\end{array}$ & Oral & $\begin{array}{c}60 \mathrm{mg} / \mathrm{kg} \\
\text { (single dose) }\end{array}$ & PK & $\begin{array}{l}\text { No adverse effects } \\
\text { Antifungal concentration } \\
\text { remains above target } \\
\text { doses for several hours }\end{array}$ & [227] \\
\hline $\begin{array}{c}\text { Terbinafine } \\
\text { hydrochloride }\end{array}$ & $\begin{array}{l}\text { African penguins } \\
\text { (Healthy) }\end{array}$ & Oral & $\begin{array}{c}3 / 7 / 15 \mathrm{mg} / \mathrm{kg} \\
\text { (single dose) } \\
15 \mathrm{mg} / \mathrm{kg} \text { sid } \\
4 \text { days }\end{array}$ & PK & $\begin{array}{l}15 \mathrm{mg} / \mathrm{kg} \text { per day oral } \\
\text { dose = putative } \\
\text { treatment } \\
\text { Slow elimination and } \\
\text { tissue accumulation }\end{array}$ & [228] \\
\hline $\begin{array}{c}\text { Terbinafine } \\
\text { hydrochloride }\end{array}$ & $\begin{array}{l}\text { Red-tailed hawks } \\
\text { (Healthy) }\end{array}$ & Oral & $\begin{array}{l}15 / 30 / 60 \mathrm{mg} / \mathrm{kg} \\
\text { (single dose) }\end{array}$ & PK & $\begin{array}{l}\text { A dose of } 22 \mathrm{mg} / \mathrm{kg} \text { SID } \\
\text { may be a potential } \\
\text { treatment option to treat } \\
\text { aspergillosis in raptors }\end{array}$ & [228] \\
\hline $\begin{array}{c}\text { Terbinafine } \\
\text { hydrochloride }\end{array}$ & $\begin{array}{l}\text { Hispanolian } \\
\text { amazons } \\
\text { (Healthy) }\end{array}$ & Oral & $\begin{array}{l}60 \mathrm{mg} / \mathrm{kg} \\
\text { (single) }\end{array}$ & PK & $\begin{array}{c}\text { No adverse effect } \\
\text { Putative treatment of } \\
\text { aspergillosis }\end{array}$ & [229] \\
\hline $\begin{array}{c}\text { Terbinafine } \\
\text { hydrochloride }\end{array}$ & $\begin{array}{l}\text { Hispanolian } \\
\text { amazons } \\
\text { (Healthy) }\end{array}$ & $\begin{array}{l}\text { Nebulization } \\
\text { (15 min) }\end{array}$ & $\begin{array}{l}1 \mathrm{mg} / \mathrm{mL} \\
\text { solution }\end{array}$ & PK & $\begin{array}{l}\text { Plasma concentration } \\
\text { above the target dose up } \\
\text { to } 4 \mathrm{~h}\end{array}$ & [218] \\
\hline $\begin{array}{l}\text { Itraconazole } \\
\text { (Itrafungol) }\end{array}$ & $\begin{array}{l}\text { African penguins } \\
\text { (Healthy) }\end{array}$ & Oral & $\begin{array}{c}20 \mathrm{mg} / \mathrm{kg} \\
\text { (single dose) }\end{array}$ & PK & $\begin{array}{l}\text { Putative cost effective } \\
\text { treatment }\end{array}$ & [230] \\
\hline $\begin{array}{l}\text { Itraconazole } \\
\text { (Itrafungol) }\end{array}$ & $\begin{array}{l}\text { Lesser flamingos } \\
\text { (Phoeniconaias } \\
\text { minor) } \\
\text { (Healthy) }\end{array}$ & Oral & $\begin{array}{c}10 \mathrm{mg} / \mathrm{kg} \\
\text { (single dose) }\end{array}$ & PK & $\begin{array}{c}\text { Plasma drug } \\
\text { concentration }> \\
0.5 \mu \mathrm{g} / \mathrm{mL} \text { maintained } \\
\text { for at least } 24 \mathrm{~h} \text { after a } \\
\text { single dose }\end{array}$ & [231] \\
\hline $\begin{array}{l}\text { Itraconazole } \\
\text { (Sporanox/powder) }\end{array}$ & $\begin{array}{l}\text { Humboldt } \\
\text { penguins }\end{array}$ & Oral (in a fish) & $\begin{array}{l}6 / 12 \mathrm{mg} / \mathrm{kg} \\
\text { SID } / \mathrm{BID} \\
14 \text { days }\end{array}$ & PK & $\begin{array}{c}8.5 \mathrm{mg} / \mathrm{kg} \text { BID or } \\
20 \mathrm{mg} / \mathrm{kg} \text { SID of } \\
\text { commercial capsule may } \\
\text { provide adequate } \\
\text { steady-state therapeutic } \\
\text { blood levels }\end{array}$ & [232] \\
\hline $\begin{array}{c}\text { Itraconazole } \\
\text { (nanoparticules) }\end{array}$ & $\begin{array}{l}\text { Japanese quail } \\
\text { (Infected) }\end{array}$ & $\begin{array}{l}\text { Nebulization } \\
\text { (30 min) }\end{array}$ & $\begin{array}{l}4 \% / 10 \% \\
\text { suspension } \\
\text { SID } 6 \text { days }\end{array}$ & EAA & $\begin{array}{l}10 \% \text { nanosuspension is } \\
\text { well tolerated and } \\
\text { alleviates acute } \\
\text { aspergillosis }\end{array}$ & [219] \\
\hline
\end{tabular}


Table 3. Cont.

\begin{tabular}{|c|c|c|c|c|c|c|}
\hline $\begin{array}{c}\text { Antifungal } \\
\text { Agent }\end{array}$ & Status/Species & $\begin{array}{c}\text { Administration } \\
\text { Route }\end{array}$ & Dose & Aim & Main Conclusions & References \\
\hline $\begin{array}{l}\text { Itraconazole } \\
\text { (nanostructured } \\
\text { lipid carries) }\end{array}$ & $\begin{array}{l}\text { Falcon (Falco sp.) } \\
\quad \text { (Healthy) }\end{array}$ & $\begin{array}{l}\text { Nebulization } \\
\quad(15 \text { min) } \\
\text { (nanonebulizer) }\end{array}$ & NS & - & $\begin{array}{l}\text { No toxic effects on } \\
\text { A594 cells } \\
\text { Penetrates deeply into } \\
\text { the respiratory tract } \\
\text { (lungs and air sacs } \\
\text { (gammascintigraphy) }\end{array}$ & [233] \\
\hline Voriconazole & $\begin{array}{l}\text { Falcons (Falco sp.) } \\
\text { (Healthy vs. } \\
\text { diseased) }\end{array}$ & $\begin{array}{l}\text { Oral (crop } \\
\text { gavage or } \\
\text { incorporated } \\
\text { into meat) }\end{array}$ & $\begin{array}{c}12.5 \mathrm{mg} / \mathrm{kg} \text { BID } \\
7 / 14 \text { days }\end{array}$ & PK/ET & $\begin{array}{l}\text { High interindividuality } \\
\text { of voriconazole/no } \\
\text { adverse effects } \\
\text { Administration in meat } \\
\text { is effective and } \\
\text { avoids tress }\end{array}$ & [234] \\
\hline Voriconazole & $\begin{array}{l}\text { African penguins } \\
\text { (Healthy) }\end{array}$ & Oral & $\begin{array}{c}5 \mathrm{mg} / \mathrm{kg} \text { (single } \\
\text { dose) } \\
5 \mathrm{mg} / \mathrm{kg} \mathrm{SID}\end{array}$ & PK & $\begin{array}{l}\text { Effective for the } \\
\text { treatment of aspergillosis } \\
\text { Potential toxicity due to } \\
\text { drug accumulation }\end{array}$ & [235] \\
\hline Voriconazole & $\begin{array}{l}\text { Magellanic } \\
\text { penguins } \\
\text { (Healthy) }\end{array}$ & $\begin{array}{l}\text { Oral (in a } \\
\text { herring) }\end{array}$ & $\begin{array}{l}2.5 / 5 \mathrm{mg} / \mathrm{kg} \\
\text { (single dose) }\end{array}$ & PK & $\begin{array}{l}\text { Above the target dose for } \\
\text { least } 24 \mathrm{~h} \text { following the } \\
\text { highest dose }\end{array}$ & [214] \\
\hline Voriconazole & $\begin{array}{l}\text { Hispanolian } \\
\text { amazons } \\
\text { (Healthy) }\end{array}$ & Oral & $\begin{array}{c}12 / 24 \mathrm{mg} / \mathrm{kg} \\
\text { (single dose) } \\
18 \mathrm{mg} / \mathrm{kg} \text { QID } \\
11 \text { days }\end{array}$ & PK & $\begin{array}{l}\text { Decrease in plasma } \\
\text { concentration following } \\
\text { administration of } \\
\text { multiple doses } \\
\text { requiring adjustment }\end{array}$ & [236] \\
\hline Voriconazole & $\begin{array}{l}\text { Red-tailed hawks } \\
\text { (Healthy) }\end{array}$ & Oral (gavage) & $\begin{array}{c}10 \mathrm{mg} / \mathrm{kg} \\
\text { (single dose) } \\
10 \mathrm{mg} / \mathrm{kg} \text { BID } \\
14 \text { days }\end{array}$ & PK & $\begin{array}{l}\text { More frequent dosing } \\
\text { (up to QID) may be } \\
\text { necessary to maintain } \\
\text { target concentration dur- } \\
\text { ing prolonged therapy }\end{array}$ & [237] \\
\hline Voriconazole & $\begin{array}{l}\text { Falcons (Falco sp.) } \\
\text { (Healthy) }\end{array}$ & $\begin{array}{l}\text { Intramuscular } \\
\text { injection }\end{array}$ & $\begin{array}{l}12.5 \mathrm{mg} / \mathrm{kg} \\
\text { (single dose) }\end{array}$ & PK & $\begin{array}{c}\text { Target plasma } \\
\text { concentration }(>1 \mu \mathrm{g} / \mathrm{ml}) \\
\text { maintained } 16 \text { to } 20 \mathrm{~h} \\
\text { without clinical } \\
\text { side effects }\end{array}$ & [215] \\
\hline Voriconazole & $\begin{array}{l}\text { Mallard ducks } \\
\text { (Healthy) }\end{array}$ & $\begin{array}{l}\text { Intravenous } \\
\text { injection } \\
\text { or oral } \\
\text { (liquid/non } \\
\text { liquid) }\end{array}$ & $\begin{array}{c}10 \mathrm{mg} / \mathrm{kg} \\
\text { (single dose) } \\
10 / 20 / 40 \mathrm{mg} / \mathrm{kg} \\
\text { (single dose) } \\
20 \mathrm{mg} / \mathrm{kg} \text { SID } \\
21 \text { days }\end{array}$ & PK & $\begin{array}{l}\text { No overt/histological } \\
\text { signs of toxicity } \\
\text { A dosing interval of at } \\
\text { least } 8-12 \mathrm{~h} \text { at a dose of } \\
20 \mathrm{mg} / \mathrm{kg} \text { may } \\
\text { be required }\end{array}$ & [238] \\
\hline Voriconazole & $\begin{array}{l}\text { Japanese quail } \\
\text { (Infected) }\end{array}$ & Oral & $\begin{array}{c}20 / 40 \mathrm{mg} / \mathrm{kg} \\
\mathrm{SID}\end{array}$ & PK/EAA & $\begin{array}{l}\text { Prolonged survival and } \\
\text { less fungal burden in the } \\
\text { lungs with the highest } \\
\text { dose. No necrotic lesions } \\
\text { (histopathology }\end{array}$ & [239] \\
\hline Voriconazole & $\begin{array}{l}\text { Rock pigeon } \\
\text { (Infected) }\end{array}$ & Oral & $\begin{array}{l}10 \mathrm{mg} / \mathrm{kg} \text { BID } \\
20 \mathrm{mg} / \mathrm{kg} \text { SID }\end{array}$ & EAA & $\begin{array}{l}\text { Reduction of clinical } \\
\text { signs and } A \text {. fumigatus } \\
\text { elimination at } \\
10 \mathrm{mg} / \mathrm{kg} \text { BID }\end{array}$ & [240] \\
\hline
\end{tabular}

BID: twice a day; EAA: experimental acute aspergillosis; ET: empirical treatment on birds with spontaneous aspergillosis; NS: not specified; PK: pharmacokinetic studies; QID: four times per day; SC: subcutaneous; SID: once per day. 
Table 4. Antifungal treatments recommended for avian aspergillosis $[4,99,241]$.

\begin{tabular}{ccr}
\hline Avian Taxon & Antifungal Agent & Dose and Administration Route \\
\hline \multirow{2}{*}{ Gamebirds } & Itraconazole & $10 \mathrm{mg} / \mathrm{kg}$ orally SID or BID \\
\cline { 2 - 3 } Parrots & Terbinafine & $15 \mathrm{mg} / \mathrm{kg}$ orally BID \\
\cline { 2 - 3 } & Amphotericin B & Nebulization $1 \mathrm{mg} / \mathrm{kg}$ diluted to $1 \mathrm{~mL}$ with sterile water BID or TID \\
\cline { 2 - 3 } & Itraconazole & $2.5-5 \mathrm{mg} / \mathrm{kg}$ orally SID in Grey parrot \\
\cline { 2 - 3 } & Voriconazole & $12-18 \mathrm{mg} / \mathrm{kg}$ orally BID \\
\hline Raptors & Itraconazole & $10 \mathrm{mg} / \mathrm{kg}$ orally BID for 60 days \\
\cline { 2 - 3 } & Terbinafine & $10-15 \mathrm{mg} / \mathrm{kg}$ orally BID for 6-8 weeks \\
\hline Seabirds & Voriconazole & $10-18 \mathrm{mg} / \mathrm{kg}$ orally BID for 60 days \\
\cline { 2 - 3 } & Itraconazole & $12.5 \mathrm{mg} / \mathrm{kg}$ orally BID in falcons \\
\hline Waterfowl & Amphotericin B & Nebulization $12.5 \mathrm{mg}$ diluted with 2.5 mL sterile water SID for 7 days \\
\hline & Itraconazole & $7.5 \mathrm{mg} / \mathrm{kg}$ intratracheally TID
\end{tabular}

BID: twice per day; TID: three times per day; SID: once per day.

\section{Prevention}

Aspergillosis prevention measures are based on two main axes: controlling the level of exposure and minimizing stressors [4].

Risk management in a natural environment is limited to the first option when it is feasible. The abandonment of crop residues on the ground and rainy weather can promote the development of molds. Under unfavorable conditions, such as periods of snow or rain, crows and waterfowl can roam and ultimately land and feed on discarded moldy grains (corn) and silage [61,62,73]. Possible but limited solutions include burying, covering, or plowing under crop residues and reducing access to contaminated fields or piles by using audible scaring devices (pyrotechnics) to redirect birds to alternative feeding areas $[2,27,242]$. Grain used for avifauna baiting, trapping, or supplemental feeding programs should be properly stored and controlled. Fallow plots for wildlife should be regularly inspected. Keeping bird feeders and nest-boxes free of moldy substrates remains essential $[2,88]$.

Captive conditions allow for finer control of the environment close to birds. As aspergillosis is not a contagious disease, multiple infections in a single enclosure involve common exposure rather than bird-to-bird spread [99]. It is useful to know the fungal loads to which animals can be exposed, especially in very sensitive species such as penguins or raptors. Air samples have been collected by sedimentation, filtration, or impaction in different environments housing birds. Bioimpactors, like the Air Strategie Bioimpactor, Surface Air Systems samplers, CIP 10-M, and Aerotech N6 (ex- Anderson N6) have been proven to be accurate tools for measuring the airborne Aspergillus concentration. The level of exposure when monitored by regular volumetric air sampling demonstrates important seasonal variations, a mitigating effect of low temperatures in cooled aviaries (Arctic and Antarctic species), and higher-risk micro-environments in multi-area structures $[43,45-47,49,51,243]$. Quantitative data are also useful to appreciate the effectiveness of filtration systems used in conventional air-handling systems to protect the most sensitive bird species, like penguins. High-Efficiency Particulate Air (HEPA) filters, although expensive and easily overloaded by the spore loads, are the best technical option but require meticulous maintenance [47]. 
In a Californian zoological park, among 22 variables tested, HEPA filters were shown to have the strongest effect (adjusted Odds Ratio $=4.33$ ) on the reduction of Aspergillus prevalence in indoor sites [244]. Higher-than-average mortality rates due to aspergillosis can be associated with hot, humid climates, which predominate in tropical aviaries where many plants with a large bulk of litter and water pools are generally present. In brown kiwi nocturnal houses, variable concentrations of $A$. fumigatus, measured as $\mathrm{CFU} / \mathrm{g}$ of wet material (soil, leaf litter), have been recovered with the highest counts following aspergillosis onset. Ground-dwelling species may be at greater risk of spore inhalation when foraging. Under stress, captive exotic birds may change their natural behaviors and spend more time on the ground foraging or hiding. By quantitatively estimating the background load levels of fungi, it becomes possible to identify inadequate litter management or storage that can promote Aspergillus growth. Regular cleaning and disinfection of the nest boxes, opening the canopy to increase the amount of sunlight reaching the floor of the aviaries, and ensuring proper ventilation help to reduce the risk of aspergillosis $[42,43,47,48,85]$.

Animal facilities, transport crates, incubators, and hatchers should be adequately ventilated and cleaned and disinfected with antifungal agents (enilconazole and essential oils) before use to keep the infection pressure low $[245,246]$. Potential sources of spores, such as moldy litter materials and feed, should never be introduced. Minimizing plantings to limit plant and soil areas and choosing artificial rather than organic material for nests must be considered for penguin exhibits $[2,46,49,119]$. Finally, an indirect way of evaluating exposure to Aspergillus spp. can consist of repeated screening of antibodies, either in the serum or in the egg yolks, as has already been done in penguins, but this requires further research $[40,41]$.

Improved animal husbandry practices minimize any stress in facilities. Birds suffering from aspergillosis can ward off the infection if it is not too severe and if global stress is minimized and the environmental quality is maximized. Broad and prolonged use of antibiotics or immunosuppressive drugs should be used with caution [107]. A 3-week prophylactic treatment with terbinafine or itraconazole in highly susceptible species of raptors is recommended by [247] in the following cases: newly captured or admitted individuals, following a change of management, extreme heat conditions, and even systematically in young reared gyrfalcons (3-120 days of age). Prophylactic protocols with itraconazole are also common in Spheniscidae held in zoo or rescued after oil spills [208,248]. In a Brazilian center [120], groups of penguins that received this antifungal prophylactically had 1.8 times fewer animals with aspergillosis when compared with non-treated birds (12.2\% versus $22.9 \%)$.

Vaccination strategies have been attempted in birds but with inconsistent results $[115,126,249,250]$.

\section{Concluding Remarks}

To go further and improve our knowledge of aspergillosis in wild birds, some data should be implemented more systematically:

As the susceptibility of the host to the disease seems to vary according to the avian species, it is necessary to identify the affected species precisely, especially in the event of an epizootic [74].

When grouped mortality occurs, possible sources should be sought as soon as possible by collecting adequate samples and investigating potential risk factors [74].

When gross findings are exuberant and promptly detected, institutions sometimes bypass histopathology or complementary diagnostic tests and conclude that "aspergillosis" was the cause of death, thus potentially underestimating the prevalence of other fungal pathogens $[30,131,251]$. The rigorous identification of a case of aspergillosis and a clinical isolate should be based exclusively on the association of an Aspergillus spp. with lesions [30,252]. 
A more systematic search for other putative etiological agents in the context of epizootics or analyses of mortality cohorts in particular, could make it possible to better understand the role of Aspergillus as an agent of primary or secondary infections [80].

Accurate identification of both common and cryptic Aspergillus species should be systematically performed in epidemiological studies. Molecular tools allowing simultaneous identification of mutations associated with a decreased sensitivity to azole antifungals such as the cyp51A gene are already available [183,221]. A systematic identification of all clinical isolates at the species level could be important to predict antifungal susceptibility or the clinical spectrum of new pathogenic species [253].

The constant difficulty of finding a single infection biomarker covering all species should prioritize the reorientation of the evaluation of these biomarkers on the species or taxa considered as priorities. Similarly, further targeted pharmacokinetic studies are necessary to improve the effectiveness of treatments on important species of birds of prey, penguins, and psittacines [210,252].

Author Contributions: Conceptualization, P.A.; writing—original draft preparation, P.A.; writingreview and editing, P.A., J.G., G.J., C.L.B. and V.R.C. All authors have read and agreed to the published version of the manuscript.

Funding: This research received no external funding.

Institutional Review Board Statement: Not applicable.

Informed Consent Statement: Not applicable.

Conflicts of Interest: The authors declare no conflict of interest.

\section{References}

1. Seyedmousavi, S.; Guillot, J.; Arné, P.; de Hoog, G.S.; Mouton, J.W.; Melchers, W.J.G.; Verweij, P.E. Aspergillus and Aspergilloses in Wild and Domestic Animals: A Global Health Concern with Parallels to Human Disease. Med. Mycol. 2015, 53, 765-797. [CrossRef]

2. Converse, K.A. Aspergillosis. In Infectious Diseases of Wild Birds; Wiley-Blackwell: Hoboken, NJ, USA, 2008; pp. 360-374. ISBN 978-0-470-34466-8.

3. Arné, P.; Lee, M.D. Fungal infections. In Diseases of Poultry; Wiley-Blackwell: Hoboken, NJ, USA, 2019; pp. 1111-1134.

4. Martel, A. Aspergillosis. In Current Therapy in Avian Medicine and Surgery; Elsevier Health Sciences: Amsterdam, The Netherlands, 2016; ISBN 978-1-4557-4671-2.

5. Arné, P.; Thierry, S.; Wang, D.; Deville, M.; Le Loc'h, G.; Desoutter, A.; Féménia, F.; Nieguitsila, A.; Huang, W.; Chermette, R.; et al. Aspergillus fumigatus in Poultry. Int. J. Microbiol. 2011, 2011. [CrossRef] [PubMed]

6. Fresenius, G. Beiträge Sur Mykologie; Brönner, M., Ed.; Frankfurt A.M.: Frankfurt, Germany, 1863.

7. Urbain, A.; Guillot, J. Les aspergilloses aviaires. In L'Oiseau et la Revue Française D'ornithologie; Société Ornithologique de France: Paris, France, 1938; pp. 559-591.

8. Houbraken, J.; Kocsubé, S.; Visagie, C.M.; Yilmaz, N.; Wang, X.-C.; Meijer, M.; Kraak, B.; Hubka, V.; Bensch, K.; Samson, R.A.; et al. Classification of Aspergillus, Penicillium, Talaromyces and Related Genera (Eurotiales): An Overview of Families, Genera, Subgenera, Sections, Series and Species. Stud. Mycol. 2020, 95, 5-169. [CrossRef]

9. Tell, L.A. Aspergillosis in Mammals and Birds: Impact on Veterinary Medicine. Med. Mycol. 2005, 43 (Suppl. 1), S71-S73. [CrossRef]

10. Tarello, W. Etiologic Agents and Diseases Found Associated with Clinical Aspergillosis in Falcons. Int. J. Microbiol. $2011,2011$. [CrossRef] [PubMed]

11. Rahim, M.A.; Bakhiet, A.O.; Hussein, M.F. Aspergillosis in a Gyrfalcon (Falco rusticolus) in Saudi Arabia. Comp. Clin. Pathol. 2013, 22, 131-135. [CrossRef]

12. Churria, C.D.G.; Reynaldi, F.; Origlia, J.; Marcantoni, H.; Píscopo, M.V.; Loyola, M.; Reinoso, E.H.; Petruccelli, M. Pulmonary Aspergillosis Due to Aspergillus Flavus Infection in a Captive Eclectus Parrot (Eclectus roratus). Braz. J. Vet. Pathol. 2012, 5, 4-6.

13. Jacobson, E.; Raphael, B.L.; Nguyen, H.T.; Greiner, E.C.; Gross, T. Avian Pox Infection, Aspergillosis and Renal Trematodiasis in a Royal Tern. J. Wildl. Dis. 1980, 16, 627-631. [CrossRef]

14. Pérez, J.; García, P.M.; Méndez, A.; Astorga, R.; Luque, I.; Tarradas, C. Outbreak of Aspergillosis in a Flock of Adult Ostriches (Struthio camelus). Vet. Rec. 2003, 153, 124-125. [CrossRef]

15. Naldo, J.L.; Samour, J.H. Causes of Morbidity and Mortality in Falcons in Saudi Arabia. J. Avian Med. Surg. 2004, 18, $229-241$. [CrossRef]

16. Silvanose, C.D.; Bailey, T.A.; Di Somma, A. Susceptibility of Fungi Isolated from the Respiratory Tract of Falcons to Amphotericin B, Itraconazole and Voriconazole. Vet. Rec. 2006, 159, 282-284. [CrossRef] 
17. Kiser, P.K.; Meritet, D.M.; Bildfell, R.J. Aspergillus Section Nigri-Associated Calcium Oxalate Crystals in an Eurasian Eagle Owl (Bubo bubo). Case Rep. Vet. Med. 2018, 2018. [CrossRef] [PubMed]

18. Lagneau, P.E.; Houtain, J.Y. Cas d'aspergillose Chez Des Perroquets En Belgique. J. Mycol. Méd. 2001, 11, 171-172.

19. Redig, P.T.; Fuller, M.R.; Evans, D.L. Prevalence of Aspergillus fumigatus in Free-Living Goshawks (Accipiter Gentilis Atricapillus). J. Wildl. Dis. 1980, 16, 169-174. [CrossRef]

20. Pal, M. Disseminated Aspergillus Terreus Infection in a Caged Pigeon. Mycopathologia 1992, 119, 137-139. [CrossRef]

21. Li, H.; Zhu, R.; She, R.; Zhang, C.; Shi, R.; Li, W.; Du, F.; Wu, Q.; Hu, F.; Zhang, Y.; et al. Case Report Associated with Aspergillosis and Hepatitis E Virus Coinfection in Himalayan Griffons. BioMed Res. Int. 2015, 2015, e287315. [CrossRef] [PubMed]

22. Payne, C.L.; Dark, M.J.; Conway, J.A.; Farina, L.L. A Retrospective Study of the Prevalence of Calcium Oxalate Crystals in Veterinary Aspergillus Cases. J. Vet. Diagn. Invest. 2017, 29, 51-58. [CrossRef]

23. Kaplan, W.; Arnstein, P.; Ajello, L.; Chandler, F.; Watts, J.; Hicklin, M. Fatal Aspergillosis in Imported Parrots. Mycopathologia 1975, 56, 25-29. [CrossRef] [PubMed]

24. Stock, B.L. Case Report: Generalized Granulomatous Lesions in Chickens and Wild Ducks Caused by Aspergillus Species. Avian Dis. 1961, 5, 89. [CrossRef]

25. Stedham, M.A.; Bucci, T.J.; Maronpot, R.R. Sexual and Asexual Phases of Aspergillus Nidulans in an Egret. Mycopathol. Mycol. Appl. 1968, 36, 289-292. [CrossRef]

26. Talbot, J.J.; Thompson, P.; Vogelnest, L.; Barrs, V.R. Identification of Pathogenic Aspergillus Isolates from Captive Birds in Australia. Med. Mycol. 2018, 56, 1038-1041. [CrossRef]

27. Friend, M. Aspergillosis. In Field Manual of Wildlife Diseases: General Field Procedures and Diseases of Birds; US Geological Survey: Washington DC, USA, 1999; pp. 129-133.

28. Perelman, B.; Kuttin, E.S. Aspergillosis in Ostriches. Avian Pathol. 1992, 21, 159-163. [CrossRef]

29. Carrasco, L.; Bautista, M.J.; de las Mulas, J.M.; Jensen, H.E. Application of Enzyme-Immunohistochemistry for the Diagnosis of Aspergillosis, Candidiasis, and Zygomycosis in Three Lovebirds. Avian Dis. 1993, 37, 923-927. [CrossRef] [PubMed]

30. Olias, P.; Gruber, A.D.; Winfried, B.; Hafez, H.M.; Lierz, M. Fungal Pneumonia as a Major Cause of Mortality in White Stork (Ciconia ciconia) Chicks. Avian Dis. 2010, 54, 94-98. [CrossRef] [PubMed]

31. Alastruey-Izquierdo, A.; Mellado, E.; Cuenca-Estrella, M. Current Section and Species Complex Concepts in Aspergillus: Recommendations for Routine Daily Practice. Ann. N. Y. Acad. Sci. 2012, 1273, 18-24. [CrossRef]

32. Gautier, M.; Normand, A.-C.; Ranque, S. Previously Unknown Species of Aspergillus. Clin. Microbiol. Infect. 2016, 22, 662-669. [CrossRef] [PubMed]

33. Vedova, R.D.; Hevia, A.; Vivot, W.; Fernández, J.; Córdoba, S.B.; Reynaldi, F.J. Aspergillosis in Domestic and Wild Birds from Argentina. Braz. J. Vet. Res. Anim. Sci. 2019, 56, e152460. [CrossRef]

34. Lim, S.Y.; Kano, R.; Ooya, K.; Kimura, S.; Yanai, T.; Hasegawa, A.; Kamata, H. The First Isolation of Aspergillus Allahabadii from a Cormorant with Pulmonary Aspergillosis. Med. Mycol. J. 2016, 57, E77-E79. [CrossRef] [PubMed]

35. Melo, A.M.; da Silva Filho, R.P.; Poester, V.R.; Fernandes, C.G.; von Groll, A.; Stevens, D.A.; Sabino, R.; Xavier, M.O. Aspergillosis in Albatrosses. Med. Mycol. 2020, 58, 852-855. [CrossRef]

36. Melo, A.; Silva-Filho, R.; Poester, V.; von Groll, A.; Fernandes, C.; Stevens, D.; Sabino, R.; Xavier, M. Aspergillosis in Free-Ranging Aquatic Birds. Med. Mycol. Case Rep. 2020, 28. [CrossRef] [PubMed]

37. Spanamberg, A.; Assis Casagrande, R.; Ferreiro, L.; Machado Rolim, V.; Oltramari de Souza, S.; Christian Magno Gonçalves, I.; Gustavo Schneider de Oliveira, L.; Wouters, F.; Terezinha Barth Wouters, A.; Suertegaray Fontana, C.; et al. Aspergillosis in green-winged saltators (Saltator similis) participants in bird singing competitions. Acta Sci. Vet. 2012, 40, 1089.

38. Sabino, R.; Burco, J.; Valente, J.; Veríssimo, C.; Clemons, K.V.; Stevens, D.A.; Tell, L.A. Molecular Identification of Clinical and Environmental Avian Aspergillus Isolates. Arch. Microbiol. 2019, 201, 253-257. [CrossRef] [PubMed]

39. Barber, A.E.; Scheufen, S.; Walther, G.; Kurzai, O.; Schmidt, V. Low Rate of Azole Resistance in Cases of Avian Aspergillosis in Germany. Med. Mycol. 2020. [CrossRef] [PubMed]

40. Graczyk, T.K.; Cockrem, J.F. Aspergillus spp. Seropositivity in New Zealand Penguins. Mycopathologia 1995, 131, 179-184. [CrossRef] [PubMed]

41. German, A.C.; Shankland, G.S.; Edwards, J.; Flach, E.J. Development of an Indirect ELISA for the Detection of Serum Antibodies to Aspergillus fumigatus in Captive Penguins. Vet. Rec. 2002, 150, 513-518. [CrossRef]

42. Perrott, J.K.; Armstrong, D.P. Aspergillus fumigatus Densities in Relation to Forest Succession and Edge Effects: Implications for Wildlife Health in Modified Environments. Ecohealth 2011, 8, 290-300. [CrossRef]

43. Burco, J.D.; Massey, J.G.; Byrne, B.A.; Tell, L.; Clemons, K.V.; Ziccardi, M.H. Monitoring of Fungal Loads in Seabird Rehabilitation Centers with Comparisons to Natural Seabird Environments in Northern California. J. Zoo Wildl. Med. 2014, 45, 29-40. [CrossRef]

44. Nardoni, S.; Ceccherelli, R.; Rossi, G.; Mancianti, F. Aspergillosis in Larus Cachinnans Micaellis: Survey of Eight Cases. Mycopathologia 2006, 161, 317-321. [CrossRef] [PubMed]

45. Dykstra, M.J.; Loomis, M.; Reininger, K.; Zombeck, D.; Faucette, T. A Comparison of Sampling Methods for Airborne Fungal Spores during an Outbreak of Aspergillosis in the Forest Aviary of the North Carolina Zoological Park. J. Zoo Wildl. Med. 1997, 28, 454-463.

46. Faucette, T.G.; Loomis, M.; Reininger, K.; Zombeck, D.; Stout, H.; Porter, C.; Dykstra, M.J. A Three-Year Study of Viable Airborne Fungi in the North Carolina Zoological Park R.J.R. Nabisco Rocky Coast Alcid Exhibit. J. Zoo Wildl. Med. 1999, $30,44-53$. 
47. Dykstra, M.J.; Reininger, K. Aviary Air-Handler Design and Its Relationship to Fungal Spore Loads in the Air. J. Zoo Wildl. Med. 2007, 38, 540-547. [CrossRef]

48. Glare, T.R.; Gartrell, B.D.; Brookes, J.J.; Perrott, J.K. Isolation and Identification of Aspergillus Spp. from Brown Kiwi (Apteryx mantelli) Nocturnal Houses in New Zealand. Avian Dis. 2014, 58, 16-24. [CrossRef] [PubMed]

49. Rivas, A.E.; Dykstra, M.J.; Kranz, K.; Bronson, E. Environmental Fungal Loads in an Indoor-Outdoor African Penguin (Spheniscus demersus) Exhibit. J. Zoo Wildl. Med. 2018, 49, 542-555. [CrossRef]

50. Guillot, C.; Arné, P.; Lécu, A.; Laidebeure, S.; Dogna, N.; Barthelemy, L.; Risco-Castillo, V.; Angebault, C.; Dannaoui, E.; Botterel, F.; et al. Aspergillus spp. Aerocontamination in a Zoological Park in France: Results of One-Year Monitoring in a Bird Nursery and Penguin Nests; Elsvier: Amsterdam, The Netherlands, 2018.

51. Fulleringer, S.L.; Seguin, D.; Warin, S.; Bezille, A.; Desterque, C.; Arné, P.; Chermette, R.; Bretagne, S.; Guillot, J. Evolution of the Environmental Contamination by Thermophilic Fungi in a Turkey Confinement House in France. Poult. Sci. 2006, 85, 1875-1880. [CrossRef]

52. Viegas, C.; Carolino, E.; Malta-Vacas, J.; Sabino, R.; Viegas, S.; Veríssimo, C. Fungal Contamination of Poultry Litter: A Public Health Problem. J. Toxicol. Environ. Health Part A 2012, 75, 1341-1350. [CrossRef]

53. Paulussen, C.; Hallsworth, J.E.; Álvarez-Pérez, S.; Nierman, W.C.; Hamill, P.G.; Blain, D.; Rediers, H.; Lievens, B. Ecology of Aspergillosis: Insights into the Pathogenic Potency of Aspergillus fumigatus and Some Other Aspergillus Species. Microb. Biotechnol. 2016, 10, 296-322. [CrossRef]

54. Korniłłowicz-Kowalska, T.; Kitowski, I. Aspergillus fumigatus and Other Thermophilic Fungi in Nests of Wetland Birds. Mycopathologia 2013, 175, 43-56. [CrossRef]

55. Hubálek, Z.; Balát, F. The Survival of Microfungi in the Nests of Tree-Sparrow [Passer montanus L.] in the Nest-Boxes over the Winter Season. Mycopathol. Mycol. Appl. 1974, 54, 517-530. [CrossRef]

56. Hubálek, Z.; Juricova, Z.; Halouzka, J. A Survey of Free-Living Birds as Hosts and Lessors' of Microbial Pathogens. Folia Zool. 1995, 44, 1-11.

57. Beer, J.V. The Incidence of Aspergillus fumigatus in the Throats of Wild Geese and Gulls. Sabouraudia 1963, 2, 238-247. [CrossRef]

58. Bellrose, F.C.; Hanson, H.C. Aspergillosis in Wood Ducks. J. Wildl. Manag. 1945, 9, 325-326. [CrossRef]

59. McDougle, H.C.; Vaught, R.W. An Epizootic of Aspergillosis in Canada Geese. J. Wildl. Manag. 1968, 32, 415-417. [CrossRef]

60. Pearson, G.L. Aspergillosis in Wintering Mallards. Bull. Wildl. Dis. Assoc. 1969, 5, 404-405. [CrossRef]

61. Zinkl, J.G.; Hyland, J.M.; Hurt, J.J. Aspergillosis in Common Crows in Nebraska, 1974. J. Wildl. Dis 1977, 13, 191-193. [CrossRef]

62. Adrian, W.J.; Spraker, T.R.; Davies, R.B. Epornitics of Aspergillosis in Mallards (Anas platyrhynchos) in North Central Colorado. J. Wildl. Dis. 1978, 14, 212-217. [CrossRef] [PubMed]

63. Becker, T.; Ahlers, A.; Hesting, S.; Haukos, D. Spatiotemporal Distribution of Waterfowl Disease Outbreaks in Kansas, USA. Prairie Nat. 2018, 50, 5-15.

64. Karstad, L.; Sileo, L. Causes of Death in Captive Wild Waterfowl in the Kortright Waterfowl Park, 1967-1970. J. Wildl. Dis. 1971, 7, 236-241. [CrossRef] [PubMed]

65. Burr, E.W. Enzootic Aspergillosis in Wild Red Vented Cockatoos in the Philippines. Mycopathologia 1981, 73, 21-23. [CrossRef] [PubMed]

66. Dyar, P.M.; Fletcher, O.J.; Page, R.K. Aspergillosis in Turkeys Associated with Use of Contaminated Litter. Avian Dis. 1984, 28, 250-255. [CrossRef]

67. Lagerquist, J.E.; Davison, M.; Foreyt, W.J. Lead Poisoning and Other Causes of Mortality in Trumpeter (Cygnus buccinator) and Tundra (C. columbianus) Swans in Western Washington. J. Wildl. Dis. 1994, 30, 60-64. [CrossRef] [PubMed]

68. Ainsworth, G.C.; Rewell, R.E. The Incidence of Aspergillosis in Captive Wild Birds. J. Comp. Pathol. Ther. 1949, 59, $213-224$. [CrossRef]

69. Brown, M.; Linton, E.; Rees, E. Causes of Mortality among Wild Swans in Britain. Wildife 1992, 43, 70-79.

70. Olsen, G.; Taylor, J.; Gee, G. Whooping Crane Mortality at Patuxent Wildlife Research Center, 1982-95. Proc. N. Am. Crane Workshop 1997, 7, 243-248.

71. Pennycott, T.W. Lead Poisoning and Parasitism in a Flock of Mute Swans (Cygnus olor) in Scotland. Vet. Rec. 1998, $142,13-17$. [CrossRef] [PubMed]

72. Sidor, I.F.; Pokras, M.A.; Major, A.R.; Poppenga, R.H.; Taylor, K.M.; Miconi, R.M. Mortality of Common Loons in New England, 1987 to 2000. J. Wildl. Dis. 2003, 39, 306-315. [CrossRef]

73. Neff, J. Outbreak of Aspergillosis in Mallards. J. Wildl. Manag. 1955, 19, 415-416. [CrossRef]

74. USGS Quarterly Wildlife Mortality Reports. Available online: https://www.usgs.gov/centers/nwhc/science/quarterly-wildlifemortality-reports?qt-science_center_objects=0\#qt-science_center_objects (accessed on 18 November 2020).

75. Astorga, R.J.; Cubero, M.J.; León, L.; Maldonado, A.; Arenas, A.; Tarradas, M.C.; Perea, A. Serological Survey of Infections in Waterfowl in the Guadalquivir Marshes (Spain). Avian Dis. 1994, 38, 371-375. [CrossRef]

76. Newman, S.H.; Chmura, A.; Converse, K.; Kilpatrick, A.M.; Patel, N.; Lammers, E.; Daszak, P. Aquatic Bird Disease and Mortality as an Indicator of Changing Ecosystem Health. Mar. Ecol. Prog. Ser. 2007, 352, 299-309. [CrossRef]

77. Franson, J.C.; Cliplef, D.J. Causes of Mortality in Common Loons. In Proceedings of the Conference on the Loon and its Ecosystem: Status Management, and Environmental Concerns, Bar Harbor, ME, USA, 22-24 August 1992; pp. 2-12. 
78. Stone, W.B.; Okoniewski, J.C. Necropsy Findings and Environmental Contaminants in Common Loons from New York. J. Wildl. Dis. 2001, 37, 178-184. [CrossRef]

79. Daoust, P.-Y.; Conboy, G.; McBurney, S.; Burgess, N. Interactive Mortality Factors in Common Loons from Maritime Canada. J. Wildl. Dis. 1998, 34, 524-531. [CrossRef]

80. Souza, M.J.; Degernes, L.A. Mortality Due to Aspergillosis in Wild Swans in Northwest Washington State, 2000-2002. J. Avian Med. Surg. 2005, 19, 98-106. [CrossRef]

81. Brand, C.J.; Windingstad, R.M.; Siegfried, L.M.; Duncan, R.M.; Cook, R.M. Avian Morbidity and Mortality from Botulism, Aspergillosis, and Salmonellosis at Jamaica Bay Wildlife Refuge, New York, USA. Colonial Waterbirds 1988, 11, 284-292. [CrossRef]

82. Fanke, J.; Wibbelt, G.; Krone, O. Mortality Factors and Diseases in Free-Ranging Eurasian Cranes (Grus grus) in Germany. J. Wildl. Dis. 2011, 47, 627-637. [CrossRef] [PubMed]

83. Work, T.M.; Dagenais, J.; Rameyer, R.; Breeden, R. Mortality Patterns in Endangered Hawaiian Geese (Nene; Branta sandvicensis). J. Wildl. Dis. 2015, 51, 688-695. [CrossRef] [PubMed]

84. Smales, I.; Miller, M.; Middleton, D.; Franklin, D. Establishment of a Captive-Breeding Programme for the Helmeted Honeyeater Lichenostomus Melanops Cassidix. Int. Zoo Yearb. 1992, 31, 57-63. [CrossRef]

85. Stiller, P. Time Budget, Foraging Activities, Diet and Occurrence of Aspergillosis in Captive Yellowheads (Mohou ochrocephala). N. Z. J. Zool. 2001, 28, 343-348. [CrossRef]

86. PROMED Aspergillosis, Birds—New Zealand: Endangered Parrot. Archive Number: 20190614.6520695. Available online: https:// www.doc.govt.nz/our-work/kakapo-recovery/what-we-do/kakapo-aspergillosis-outbreak/ (accessed on 18 November 2020).

87. Cork, S.C.; Alley, M.R.; Johnstone, A.C.; Stockdale, P.H. Aspergillosis and Other Causes of Mortality in the Stitchbird in New Zealand. J. Wildl. Dis. 1999, 35, 481-486. [CrossRef]

88. Alley, M.R.; Castro, I.; Hunter, J.E. Aspergillosis in Hihi (Notiomystis cincta) on Mokoia Island. N. Z. Vet. J. 1999, 47, 88-91. [CrossRef]

89. Armstrong, D.P.; Castro, I.; Alley, J.C.; Feenstra, B.; Perrott, J.K. Mortality and Behaviour of Hihi, an Endangered New Zealand Honeyeater, in the Establishment Phase Following Translocation. Biol. Conserv. 1999, 89, 329-339. [CrossRef]

90. Kocan, R.M.; Perry, M.C. Infection and Mortality in Captive Wild-Trapped Canvasback Ducks. J. Wildl. Dis. 1976, 12, 30-33. [CrossRef] [PubMed]

91. Hillgarth, N.; Kear, J. Diseases of Perching Ducks in Captivity. Wildfowl 1981, 32, 156-163.

92. Hillgarth, N.; Kear, J.; Horký, K. Mortality of the Northern Geese in Captivity. Wildfowl 1983, 34, 153-162.

93. Coon, N.C.; Locke, L.N. Aspergillosis in a Bald Eagle (Haliaeetus leucocephalus). Bull. Wildl. Dis. Assoc. 1968, 4, 51. [CrossRef] [PubMed]

94. Kaliner, G.; Cooper, J.E. Dual Infection of an African Fish Eagle with Acid-Fast Bacilli and an Aspergillus Sp. J. Wildl. Dis. 1973, 9, 51-55. [CrossRef]

95. Wobeser, G.; Saunders, J.R. Pulmonary Oxalosis in Association with Aspergillus Niger Infection in a Great Horned Owl (Bubo virginianus). Avian Dis. 1975, 19, 388-392. [CrossRef]

96. Mihaylov, G.; Petrov, V.; Marutsov, P.; Simeonov, R.; Simeonova, G. A Case of Aspergillosis in a Bearded Vulture (Gypaetos barbatus). Trakia J. Sci. 2008, 6, 144-146.

97. Jung, K.; Kim, Y.; Lee, H.; Kim, J.-T. Aspergillus fumigatus Infection in Two Wild Eurasian Black Vultures (Aegypius Monachus Linnaeus) with Carbofuran Insecticide Poisoning: A Case Report. Vet. J. 2009, 179, 307-312. [CrossRef]

98. Sato, Y.; Itagaki, T. Fungal Airsacculitis Associated with Multiple Helminth Infestations in a Black-Eared Kite (Milvus migrans). Avian Dis. 2010, 54, 965-968. [CrossRef]

99. Redig, P. Aspergillosis. In Avian Medicine; Samour, J., Ed.; Mosby: London, UK, 2000; pp. 275-287.

100. Russell, R.E.; Franson, J.C. Causes of Mortality in Eagles Submitted to The National Wildlife Health Center 1975-2013. Wildl. Soc. Bull. 2014, 38, 697-704. [CrossRef]

101. McMillan, M.C.; Petrak, M.L. Retrospective Study of Aspergillosis in Pet Birds. Available online: https://eurekamag.com/ research/002/211/002211598.php (accessed on 27 October 2020).

102. Tsai, S.S.; Park, J.H.; Hirai, K.; Itakura, C. Aspergillosis and Candidiasis in Psittacine and Passeriforme Birds with Particular Reference to Nasal Lesions. Avian Pathol. 1992, 21, 699-709. [CrossRef] [PubMed]

103. Dallwig, R.K.; Hanley, C.S.; Ballegeer, E.A.; Steinberg, H. What Is Your Diagnosis? J. Am. Vet. Med. Assoc. 2007, 231, 205-206. [CrossRef] [PubMed]

104. Villar, D.; Kramer, M.; Howard, L.; Hammond, E.; Cray, C.; Latimer, K. Clinical Presentation and Pathology of Sarcocystosis in Psittaciform Birds: 11 Cases. Avian Dis. 2008, 52, 187-194. [CrossRef] [PubMed]

105. Cray, C.; Watson, T.; Arheart, K.L. Serosurvey and Diagnostic Application of Antibody Titers to Aspergillus in Avian Species. Avian Dis. 2009, 53, 491-494. [CrossRef]

106. Nemeth, N.M.; Gonzalez-Astudillo, V.; Oesterle, P.T.; Howerth, E.W. A 5-Year Retrospective Review of Avian Diseases Diagnosed at the Department of Pathology, University of Georgia. J. Comp. Pathol. 2016, 155, 105-120. [CrossRef] [PubMed]

107. Verstappen, F.A.L.M.; Dorrestein, G.M. Aspergillosis in Amazon Parrots After Corticosteroid Therapy for Smoke-Inhalation Injury. J. Avian Med. Surg. 2005, 19, 138-141. [CrossRef]

108. Obendorf, D.L.; McColl, K. Mortality in Little Penguins (Eudyptula minor) along the Coast of Victoria, Australia. J. Wildl. Dis. 1980, 16, 251-259. [CrossRef] 
109. White, F.H.; Forrester, D.J.; Nesbitt, S.A. Salmonella and Aspergillus Infections in Common Loons Overwintering in Florida. J. Am. Vet. Med. Assoc. 1976, 169, 936-937.

110. Forrester, D.J.; Davidson, W.R.; Lange, R.E.; Stroud, R.K.; Alexander, L.L.; Franson, J.C.; Haseltine, S.D.; Littell, R.C.; Nesbitt, S.A. Winter Mortality of Common Loons in Florida Coastal Waters. J. Wildl. Dis. 1997, 33, 833-847. [CrossRef]

111. Jauniaux, T.; Brosens, L.; Coignoul, F. Lesions Observed on Stranded Seabirds along the Belgian Coast from 1992 to 1995. ICES J. Mar. Sci. 1997, 54, 714-717. [CrossRef]

112. Brown, M.J.; Linton, E.; Rees, E.C. Diseases of Swans in Captivity. Wildfowl 1992, 43, 58-69.

113. Hillgarth, N.; Kear, J. Diseases of Seaducks in Captivity. Wildfowl 1979, 30, 135-141.

114. Hillgarth, N.; Kear, J. Causes of Mortality among Whistling Ducks in Captivity. Wildfowl 1982, 33, $133-139$.

115. Flach, E.J.; Stevenson, M.F.; Henderson, G.M. Aspergillosis in Gentoo Penguins (Pygoscelis papua) at Edinburgh Zoo, 1964 to 1988. Vet. Rec. 1990, 126, 81-85. [PubMed]

116. Fix, A.S.; Waterhouse, C.; Greiner, E.C.; Stoskopf, M.K. Plasmodium Relictum as a Cause of Avian Malaria in Wild-Caught Magellanic Penguins (Spheniscus magellanicus). J. Wildl. Dis. 1988, 24, 610-619. [CrossRef]

117. Krol, L.; Moore, R.P.; Mutlow, A.G.; Brady, S.M.; Dorsa, D. A Retrospective Analysis of Mortality in Captive Magellanic Penguins (Spheniscus magellanicus) in the United States, 2008-2018. Zoo Biol. 2020, 39, 405-410. [CrossRef] [PubMed]

118. Gibson, D.J.; Nemeth, N.M.; Beaufrère, H.; Varga, C.; Eagalle, T.; Susta, L. Captive Psittacine Birds in Ontario, Canada: A 19-Year Retrospective Study of the Causes of Morbidity and Mortality. J. Comp. Pathol. 2019, 171, 38-52. [CrossRef]

119. Xavier, M.O.; Soares, M.P.; Meinerz, A.R.M.; Nobre, M.O.; Osório, L.G.; da Silva Filho, R.P.; Meireles, M.C.A. Aspergillosis: A Limiting Factor during Recovery of Captive Magellanic Penguins. Braz. J. Microbiol. 2007, 38, 480-484. [CrossRef]

120. da Silva Filho, R.P.; Xavier, M.O.; Martins, A.M.; Ruoppolo, V.; Mendoza-Sassi, R.A.; Adornes, A.C.; Cabana, Â.L.; Meireles, M.C.A. Incidence Density, Proportionate Mortality, and Risk Factors of Aspergillosis in Magellanic Penguins in a Rehabilitation Center from Brazil. J. Zoo Wildl. Med. 2015, 46, 667-674. [CrossRef]

121. Nakeeb, S.M.; Babus, B.; Clifton, A.Y. Aspergillosis in the Peruvian Penguin (Spheniscus humboldti). J. Zoo Anim. Med. 1981, 12, 51-54. [CrossRef]

122. Tuttle, A.D.; Andreadis, T.G.; Frasca, S.; Dunn, J.L. Eastern Equine Encephalitis in a Flock of African Penguins Maintained at an Aquarium. J. Am. Vet. Med. Assoc. 2005, 226, 2059-2062. [CrossRef] [PubMed]

123. Alvarez-Perez, S.; Mateos, A.; Dominguez, L.; Martinez-Nevado, E.; Blanco, J.L.; Garcia, M.E. Polyclonal Aspergillus fumigatus Infection in Captive Penguins. Vet. Microbiol. 2010, 144, 444-449. [CrossRef]

124. Xavier, M.O.; Soares, M.P.; Cabana, A.L.; da Silva-Filho, R.P.; Ruoppolo, V.; Meireles, M.C.A.; Severo, L.C. Clinical and Pathological Findings of Aspergillosis in Magellanic Penguins (Spheniscus magellanicus). Cienc. Anim. Bras. 2011, 12, 520-524. [CrossRef]

125. Vahsen, T.; Zapata, L.; Guabiraba, R.; Melloul, E.; Cordonnier, N.; Botterel, F.; Guillot, J.; Arné, P.; Risco-Castillo, V. Cellular and Molecular Insights on the Regulation of Innate Immune Responses to Experimental Aspergillosis in Chicken and Turkey Poults. Med. Mycol. 2020. [CrossRef]

126. Joseph, V. Aspergillosis in Raptors. Semin. Avian Exot. Pet Med. 2000, 9, 52-58. [CrossRef]

127. Monroe, A.; Noah, P.; Brown, S. Comparison of Medical Treatment Regimes for Aspergillosis in Captive Tufted Puffins. Penguin Conserv. 1994, 7, 1-5.

128. Atasever, A.; Beyaz, L.; Kibar, M.; Gümüssoy, K. A Case of Tuberculosis and Aspergillosis in a Long-Legged Buzzard (Buteo rufinus). Rev. Méd. Vét. 2006, 157, 26-29.

129. Chege, S.; Howlett, J.; Al Qassimi, M.; Toosy, A.; Kinne, J.; Obanda, V. Opportunistic Infection of Aspergillus and Bacteria in Captive Cape Vultures (Gyps coprotheres). Asian Pac. J. Trop. Biomed. 2013, 3, 401-406. [CrossRef]

130. Kang, H.-M.; Jang, H.-J.; Seo, M.-K.; Lee, J.-W.; Na, K.-J. Psittacine Beak and Feather Disease, Budgerigar Fledgling Disease and Aspergillosis in an African Grey Parrot (Psittacus erithacus). J. Vet. Clin. 2017, 34, 310-312. [CrossRef]

131. Cabana, Â.; Vanstreels, R.; Xavier, M.; Osório, L.; Adornes, A.; Meirelles Leite, A.; Pereira Soares, M.; Silva-Filho, R.; Catão-Dias, J.; Meireles, M. Lethal Concurrent Avian Malaria and Aspergillosis in Magellanic Penguin (Spheniscus magellanicus). Bol. Chil. Ornitol. 2014, 20, 28-32.

132. Young, E.A.; Cornish, T.E.; Little, S.E. Concomitant Mycotic and Verminous Pneumonia in a Blue Jay from Georgia. J. Wildl. Dis. 1998, 34, 625-628. [CrossRef] [PubMed]

133. Beaudette, F.R. Aspergillosis and Parasitism in a Gull. Bird Band. 1945, 16, 99-101. [CrossRef]

134. Stabler, R.M.; Hamilton, M.A. Aspergillosis, Trichomoniasis, and Drug Therapy in a Gyrfalcon. Auk 1954, 71, 205-208. [CrossRef]

135. Ward, F.P.; Fairchild, D.G.; Vuicich, J.V. Pulmonary Aspergillosis in Prairie Falcon Nest Mates. J. Wildl. Dis. 1970, 6, 80-83. [CrossRef]

136. Tamam, O. Pulmonary Aspergillosis in Imported Great Blue Turaco. Assiut Vet. Med. J. 2015, 61, 80-86.

137. van Cutsem, J.; Fransen, J. Fungal Infections in Birds in Captivity—Six Case Reports. Mycoses 1987, 30, 166-171. [CrossRef] [PubMed]

138. Bailey, T.; Silvanose, C.-D.; Naldo, J.; Combreau, O.; Launay, F.; Wernery, U.; Kinne, J.; Gough, R.; Manvell, R. Health Considerations of the Rehabilitation of Illegally Traded Houbara Bustards Chlamydotis Undulata Macqueenii in the Middle East. Oryx 2000, 34, 325-334. [CrossRef]

139. Friend, M.; Trainer, D.O. Aspergillosis in Captive Herring Gulls. J. Wildl. Dis. 1969, 5, 271-275. [CrossRef] 
140. Horowitz, D.B.; Haebler, R. Demonstration of Aspergillus sp. in Tissues of the Common Loon, Gavier Immer: Incidence, Progression, and Severity. J. Histotechnol. 2001, 24, 101-106. [CrossRef]

141. Dréan-Quénec'Hdu, S.L.; Ferlaux, C. Problèmes pathologiques secondaires à la captivité de la faune sauvage: Exemple des oiseaux marins mazoutés. Rev. Méd. Vét. 2002, 153, 109-120.

142. Balseiro, A.; Espí, A.; Márquez, I.; Pérez, V.; Ferreras, M.C.; Marín, J.F.G.; Prieto, J.M. Pathological Features in Marine Birds Affected by the Prestige's Oil Spill in the North of Spain. J. Wildl. Dis. 2005, 41, 371-378. [CrossRef] [PubMed]

143. Gartrell, B.D.; Collen, R.; Dowding, J.E.; Gummer, H.; Hunter, S.; King, E.J.; Laurenson, L.; Lilley, C.D.; Morgan, K.J.; McConnell, H.M.; et al. Captive Husbandry and Veterinary Care of Northern New Zealand Dotterels (Charadrius Obscurus Aquilonius) during the CV Rena Oil-Spill Response. Wildl. Res. 2013, 40, 624-632. [CrossRef]

144. Hoppes, S.; Gurfield, N.; Flammer, K.; Colitz, C.; Fisher, P. Mycotic Keratitis in a Blue-Fronted Amazon Parrot (Amazona aestiva). J. Avian Med. Surg. 2000, 14, 185-189. [CrossRef]

145. Abrams, G.A.; Paul-Murphy, J.; Ramer, J.C.; Murphy, C.J. Aspergillus Blepharitis and Dermatitis in a Peregrine Falcon-Gyrfalcon Hybrid (Falco peregrinus x Falco rusticolus). J. Avian Med. Surg. 2001, 15, 114-120. [CrossRef]

146. Atasever, A.; Gümüşsoy, K.S. Pathological, Clinical and Mycological Findings in Experimental Aspergillosis Infections of Starlings. J. Vet. Med. Ser. A 2004, 51, 19-22. [CrossRef] [PubMed]

147. Beernaert, L.A.; Pasmans, F.; Haesebrouck, F.; Martel, A. Modelling Aspergillus fumigatus Infections in Racing Pigeons (Columba Livia Domestica). Avian Pathol. 2008, 37, 545-549. [CrossRef] [PubMed]

148. Van Waeyenberghe, L.; Pasmans, F.; D’Herde, K.; Ducatelle, R.; Favoreel, H.; Li, S.-J.; Haesebrouck, F.; Martel, A. Germination of Aspergillus fumigatus inside Avian Respiratory Macrophages Is Associated with Cytotoxicity. Vet. Res. 2012, 43, 1-5. [CrossRef]

149. Wernery, U.; Tsang, C.-C.; Hebel, C.; Damerau, A.; Kinne, J.; Cai, J.-P.; Küspert, H.; Chan, K.-F.; Joseph, M.; Xue, S.; et al. Serodiagnosis of Aspergillosis in Falcons (Falco Spp.) by an Afmp1p-Based Enzyme-Linked Immunosorbent Assay. Mycoses 2018, 61, 600-609. [CrossRef]

150. Chaudhary, S.K.; Sadana, J.R. Experimental Aspergillosis in Japanese Quails (Coturnix coturnix japonica). Clinical Signs and Haematological Changes. Mycopathologia 1988, 102, 179-184. [CrossRef] [PubMed]

151. Schulz, J.; Sanchéz, A.; Lierz, M.; Hartung, J.; Aland, A. Dead Losses of Falcons Caused by Aspergillosis. In XIII. International Congress on Animal Hygiene ISAH; Estonia Estonian University of Life Sciences Tartu: Tartu, Estonia, $2007 ;$ pp. $707-711$.

152. Corbanie, E.A.; Matthijs, M.G.R.; Van Eck, J.H.H.; Remon, J.P.; Landman, W.J.M.; Vervaet, C. Deposition of Differently Sized Airborne Microspheres in the Respiratory Tract of Chickens. Avian Pathol. 2007, 35, 475-485. [CrossRef]

153. Fedde, M.R. Relationship of Structure and Function of the Avian Respiratory System to Disease Susceptibility. Poult. Sci. 1998, 77, 1130-1138. [CrossRef]

154. Reese, S.; Dalamani, G.; Kaspers, B. The Avian Lung-Associated Immune System: A Review. Vet. Res. 2006, 37, 311-324. [CrossRef]

155. Brown, R.E.; Brain, J.D.; Wang, N. The Avian Respiratory System: A Unique Model for Studies of Respiratory Toxicosis and for Monitoring Air Quality. Environ. Health Perspect. 1997, 105, 188-200. [CrossRef] [PubMed]

156. Cacciuttolo, E.; Rossi, G.; Nardoni, S.; Legrottaglie, R.; Mani, P. Anatomopathological Aspects of Avian Aspergillosis. Vet. Res. Commun. 2009, 33, 521-527. [CrossRef]

157. Latif, H.; Gross, M.; Fischer, D.; Lierz, M.; Usleber, E. Immunochemical Analysis of Fumigaclavine Mycotoxins in Respiratory Tissues and in Blood Serum of Birds with Confirmed Aspergillosis. Mycotoxin Res. 2015, 31, 177-183. [CrossRef] [PubMed]

158. Richard, J.L.; Dvorak, T.J.; Ross, P.F. Natural Occurrence of Gliotoxin in Turkeys Infected with Aspergillus fumigatus, Fresenius. Mycopathologia 1996, 134, 167-170. [CrossRef]

159. Richard, J.L.; Peden, W.M.; Williams, P.P. Gliotoxin Inhibits Transformation and Its Cytotoxic to Turkey Peripheral Blood Lymphocytes. Mycopathologia 1994, 126, 109-114. [CrossRef] [PubMed]

160. Quist, C.F.; Cornish, T.; Wyatt, R.D. Mycotoxicosis. In Infectious Diseases of Wild Birds; John Wiley \& Sons, Ltd.: Hoboken, NJ, USA, 2007; pp. 417-430. ISBN 978-0-470-34466-8.

161. Lawson, B.; Robinson, R.A.; Toms, M.P.; Risely, K.; MacDonald, S.; Cunningham, A.A. Health Hazards to Wild Birds and Risk Factors Associated with Anthropogenic Food Provisioning. Philos. Trans. R. Soc. B Biol. Sci. 2018, 373, 20170091. [CrossRef]

162. Olias, P.; Gruber, A.D.; Hafez, H.M.; Lierz, M.; Slesiona, S.; Brock, M.; Jacobsen, I.D. Molecular Epidemiology and Virulence Assessment of Aspergillus fumigatus Isolates from White Stork Chicks and Their Environment. Vet. Microbiol. 2011, 148, 348-355. [CrossRef]

163. Fatunmbi, O.O.; Bankole, A. Severe Disseminated Aspergillosis in a Captive Abyssinian Tawny Eagle (Aquila rapax Raptor). J. Wildl. Dis. 1984, 20, 52-54. [CrossRef]

164. Fischer, D.; Van Waeyenberghe, L.; Failing, K.; Martel, A.; Lierz, M. Single Tracheal Inoculation of Aspergillus fumigatus Conidia Induced Aspergillosis in Juvenile Falcons (Falco Spp.). Avian Pathol. 2018, 47, 33-46. [CrossRef]

165. Simpson, V. Spinal Aspergillosis in Pheasants. Veterinary Record 2011, 169, 562. [CrossRef]

166. Greenacre, C.B.; Latimer, K.S.; Ritchie, B.W. Leg Paresis in a Black Palm Cockatoo (Probosciger aterrimus) Caused by Aspergillosis. J. Zoo Wildl. Med. 1992, 23, 122-126.

167. Hurley-Sanders, J.L.; Larsen, R.S.; Troan, B.; Loomis, M. Fungal Osteomyelitis in Two Bufflehead Ducklings (Bucephala albeola). J. Zoo Wildl. Med. 2015, 46, 613-616. [CrossRef] [PubMed] 
168. Weller, J.; Phalen, D.N. Self-Mutilation in Parrots with Aspergillosis. In Proceedings of the Association Avian Veterinarians Australasian Committee Annual Conference, Melbourne, VIC, Australia, Melbourne, VIC, Australia, 3-7 September 2012; pp. $115-120$.

169. Yates, V.J.; Miller, L.T.; Jasty, V.; Willey, C.H.; Holtzinger, M. Web Necrosis in Mute Swans-A Report of an Outbreak. J. Wildl. Dis. 1969, 5, 33-34. [CrossRef]

170. Locke, L.N.; Young, L.T. Aspergillosis in a Common Loon (Gavis immer). Bull. Wildl. Dis. Assoc. 1967, 3, 34-35. [CrossRef]

171. Leotta, M.P.; Pelegrina, M.; Cáceres, A. Invasive pulmonary aspergillosis in a captive bird Cyanocompsa brissonii (Cardinalidae) in Mendoza, Argentina. Rev. Vet. 2016, 26, 79-81. [CrossRef]

172. Barathidasan, R.; Singh, S.D.; Saini, M.; Sharma, A.K.; Dhama, K. The First Case of Angioinvasive Pulmonary Aspergillosis in a Himalayan Griffon Vulture (Gyps himalayensis). Avian Biol. Res. 2013, 6, 302-306. [CrossRef]

173. Bicknell, E.J.; Greichus, A.; Greichus, Y.A.; Bury, R.J.; Knudtson, W.U. Diagnosis and Treatment of Aspergillosis in Captive Cormorants. Sabouraudia 1971, 9, 119-122. [CrossRef]

174. Westerhof, I. Treatment of Tracheal Obstruction in Psittacine Birds Using a Suction Technique: A Retrospective Study of 19 Birds. J. Avian Med. Surg. 1995, 9, 45-49.

175. Wolff, P.L.; Petrini, K.R.; Kolmstetter, C. An Outbreak of Aspergillosis in Crested Wood Partridges (Rollulus rouloul). J. Zoo Wildl. Med. 1992, 23, 108-112.

176. Carrasco, L.; Lima, J.S.; Halfen, D.C.; Salguero, F.J.; Sánchez-Cordon, P.; Becker, G. Systemic Aspergillosis in an Oiled Magallanic Penguin (Spheniscus magellanicus). J. Vet. Med. B Infect. Dis Vet. Public Health 2001, 48, 551-554. [CrossRef]

177. Low, M.; Berggren, A.; Morgan, K.J.; Alley, M.R. Aspergillosis in a North Island Robin (Petroica longipes). N. Z. Vet. J. 2005, 53, 462-464. [CrossRef] [PubMed]

178. Gulcubuk, A.; Erdogan-Bamac, O.; Metiner, K.; Ozturk, G.Y.; Ozgur, Y.; Haktanir, D. A Case of Pulmonary Aspergillosis in White Storks. J. Hell. Vet. Med. Soc. 2018, 69, 1004-1009. [CrossRef]

179. Chiu, P.; Chan, F.; Chen, L.; Shyu, C.; Lin, P.; Wang, L.; Chen, K.; Lin, C.; Chang, W.; Liao, J. Case Report: Pyogranulomatous Aspergillosis in an Endemic Formosan Blue Magpie (Urocissa caerulea). Taiwan Vet. J. 2010, 36, 18-22. [CrossRef]

180. Guarner, J.; Brandt, M.E. Histopathologic Diagnosis of Fungal Infections in the 21st Century. Clin. Microbiol. Rev. 2011, 24, 247-280. [CrossRef] [PubMed]

181. Olias, P.; Jacobsen, I.D.; Gruber, A.D. Fungal Species Identification from Avian Lung Specimens by Single Hypha Laser Microdissection and PCR Product Sequencing. Med. Mycol. 2011, 49, 56-61. [CrossRef] [PubMed]

182. Nouri, M.; Tavasoli, A.; Arabkhazaeli, F. Dual Infection of Respiratory Tract with an Aspergillus Sp. and Bacilli in a Canary (Serinus canarius). Res. J. Poult. Sci. 2013, 6, 33-37.

183. Savelieff, M.G.; Pappalardo, L.; Azmanis, P. The Current Status of Avian Aspergillosis Diagnoses: Veterinary Practice to Novel Research Avenues. Vet. Clin. Pathol. 2018, 47, 342-362. [CrossRef] [PubMed]

184. Jensen, H.E.; Christensen, J.P.; Bisgaard, M.; Nielsen, O.L. Immunohistochemistry for the Diagnosis of Aspergillosis in Turkey Poults. Avian Pathol. 1997, 26, 5-18. [CrossRef]

185. Jones, M.P.; Orosz, S.E. The Diagnosis of Aspergillosis in Birds. Semin. Avian Exot. Pet Med. 2000, 9, 52-58. [CrossRef]

186. Ivey, E.S. Serologic and Plasma Protein Electrophoretic Findings in 7 Psittacine Birds with Aspergillosis. J. Avian Med. Surg. 2000, 14, 103-106. [CrossRef]

187. Cray, C.; Watson, T.; Rodriguez, M.; Arheart, K.L. Application of Galactomannan Analysis and Protein Electrophoresis in the Diagnosis of Aspergillosis in Avian Species. J. Zoo Wildl. Med. 2009, 40, 64-70. [CrossRef]

188. Cray, C.; Reavill, D.; Romagnano, A.; Van Sant, F.; Champagne, D.; Stevenson, R.; Rolfe, V.; Griffin, C.; Clubb, S. Galactomannan Assay and Plasma Protein Electrophoresis Findings in Psittacine Birds with Aspergillosis. J. Avian Med. Surg. 2009, 23, 125-135. [CrossRef]

189. Kummrow, M.; Silvanose, C.; Somma, A.D.; Bailey, T.A.; Vorbrüggen, S. Serum Protein Electrophoresis by Using High-Resolution Agarose Gel in Clinically Healthy and Aspergillus Species-Infected Falcons. J. Avian Med. Surg. 2012, 26, 213-220. [CrossRef] [PubMed]

190. Fischer, D.; Van Waeyenberghe, L.; Cray, C.; Gross, M.; Usleber, E.; Pasmans, F.; Martel, A.; Lierz, M. Comparison of Diagnostic Tools for the Detection of Aspergillosis in Blood Samples of Experimentally Infected Falcons. Avian Dis. 2014, 58, 587-598. [CrossRef]

191. Desoubeaux, G.; Rodriguez, M.; Bronson, E.; Sirpenski, G.; Cray, C. Application of 3-Hydroxybutyrate Measurement and Plasma Protein Electrophoresis in the Diagnosis of Aspergillosis in African Penguins (Spheniscus demersus). J. Zoo Wildl. Med. 2018, 49, 696-703. [CrossRef] [PubMed]

192. Caliendo, V.; McKinney, P.; Bailey, T.; Kinne, J.; Wernery, U. Serum Amyloid A as an Indicator of Health Status in Falcons. J. Avian Med. Surg. 2013, 27, 83-89. [CrossRef] [PubMed]

193. Goetting, V.; Lee, K.A.; Woods, L.; Clemons, K.V.; Stevens, D.A.; Tell, L.A. Inflammatory Marker Profiles in an Avian Experimental Model of Aspergillosis. Med. Mycol. 2013, 51, 696-703. [CrossRef]

194. Latgé, J.-P.; Chamilos, G. Aspergillus fumigatus and Aspergillosis in 2019. Clin. Microbiol. Rev. 2019, 33. [CrossRef] [PubMed]

195. Arca-Ruibal, B.; Wernery, U.; Zachariah, R.; Bailey, T.A.; Di Somma, A.; Silvanose, C.; McKinney, P. Assessment of a Commercial Sandwich ELISA in the Diagnosis of Aspergillosis in Falcons. Vet. Rec. 2006, 158, 442-444. [CrossRef] 
196. Cabana, A.L.; Xavier, M.O.; Mendes, J.F.; Teles, A.J.; Martins, A.M.; Silva-Filho, R.P.; Meireles, M.C.A.; Cabana, A.L.; Xavier, M.O.; Mendes, J.F.; et al. Applicability of the Platelia EIA ${ }^{\circledR}$ Aspergillus Test for the Diagnosis of Aspergilosis in Penguins. Braz. J. Biol. 2019, 79, 169-173. [CrossRef]

197. Burco, J.D.; Ziccardi, M.H.; Clemons, K.V.; Tell, L.A. Evaluation of Plasma (1->3) Beta-D-Glucan Concentrations in Birds Naturally and Experimentally Infected with Aspergillus fumigatus. Avian Dis. 2012, 56, 183-191. [CrossRef]

198. Katz, M.E.; Love, S.C.; Gill, H.S.; Cheetham, B.F. Development of a Method for the Identification, Using the Polymerase Chain Reaction, of Aspergillus fumigatus Isolated from Ostriches. Aust. Vet. J. 1996, 74, 50-54. [CrossRef]

199. Melloul, E.; Thierry, S.; Durand, B.; Cordonnier, N.; Desoubeaux, G.; Chandenier, J.; Bostvironnois, C.; Botterel, F.; Chermette, R.; Guillot, J.; et al. Assessment of Aspergillus fumigatus Burden in Lungs of Intratracheally-Challenged Turkeys (Meleagris gallopavo) by Quantitative PCR, Galactomannan Enzyme Immunoassay, and Quantitative Culture. Comp. Immunol. Microbiol. Infect. Dis. 2014, 37, 271-279. [CrossRef] [PubMed]

200. Morishita, T.Y.; McFadzen, M.E.; Mohan, R.; Aye, P.P.; Brooks, D.L. Serologic Survey of Free-Living Nestling Prairie Falcons (Falco mexicanus) for Selected Pathogens. J. Zoo Wildl. Med. 1998, 29, 18-20.

201. Sanchez, C.R.; Murray, S.Z. Diagnosis and Successful Treatment of a Presumptive Case of Aspergillosis in a Micronesian Kingfisher (Halcyon Cinnamomina Cinnamomina). Avian Dis. 2005, 49, 309-312. [CrossRef] [PubMed]

202. Desoubeaux, G.; Cray, C. Animal Models of Aspergillosis. Comp. Med. 2018, 68, 109-123.

203. Stetter, M.; Mangold, B.; Calle, P.; Raphael, B.; Trupkiewicz, J.; Harmati, N.; Cook, R. Aspergillosis in Captive Pacific Eiders (Somateris mollissimu). In Proceedings of the International Association for Aquatic Animal Medicine, Vallejo, CA, USA, 10 May 1994; Volume 25, pp. 110-117.

204. Vorbrüggen, S.; Bailey, T.; Krautwald-Junghanns, M.-E. Röntgenzeichen bei an Mykose des Respirationstrakts erkrankten Greifvögeln. Tierarztl. Prax. Ausg. K Kleintiere Heimtiere 2013, 41, 311-318. [CrossRef] [PubMed]

205. Schwarz, T.; Kelley, C.; Pinkerton, M.E.; Hartup, B.K. Computed Tomographic Anatomy and Characteristics of Respiratory Aspergillosis in Juvenile Whooping Cranes. Vet. Radiol. Ultrasound 2016, 57, 16-23. [CrossRef] [PubMed]

206. Fischer, D.; Lierz, M. Diagnostic Procedures and Available Techniques for the Diagnosis of Aspergillosis in Birds. J. Exot. Pet. Med. 2015, 24, 283-295. [CrossRef]

207. Orosz, S.E. Overview of Aspergillosis: Pathogenesis and Treatment Options. Semin. Avian Exot. Pet. Med. 2000, 9, 59-65. [CrossRef]

208. Beernaert, L.A.; Pasmans, F.; Waeyenberghe, L.V.; Haesebrouck, F.; Martel, A. Aspergillus Infections in Birds: A Review. Avian Pathol. 2010, 39, 325-331. [CrossRef]

209. Divers, S.J. Avian Endosurgery. Vet. Clin. Exot. Anim. Pract. 2010, 13, 203-216. [CrossRef] [PubMed]

210. Antonissen, G.; Martel, A. Antifungal Therapy in Birds: Old Drugs in a New Jacket. Vet. Clin. N. Am. Exot. Anim. Pract. 2018, 21, 355-377. [CrossRef]

211. Bonar, C.J.; Lewandowski, A.H. Use of a Liposomal Formulation of Amphotericin B for Treating Wound Aspergillosis in a Goliath Heron (Ardea goliath). J. Avian Med. Surg. 2004, 18, 162-166. [CrossRef]

212. Scope, A.; Burhenne, J.; Haefel, W.; Hess, M. Species Dependent Differences and Evaluation of Possible Influences on the Enteral Absorption of Voriconazole in Birds. In Proceedings of the 9th European Conference of the Association of Avian Veterinarians, 7th Scientific ECAMS Meeting of the European College of Avian Medicine and Surgery, Zürich, Switzerland, 27-31 March 2007; Volume 236.

213. Somma, A.D.; Bailey, T.; Silvanose, C.; Garcia-Martinez, C. The Use of Voriconazole for the Treatment of Aspergillosis in Falcons (Falco species). J. Avian Med. Surg. 2007, 21, 307-317. [CrossRef]

214. Parsley, R.A.; Tell, L.A.; Gehring, R. Pharmacokinetics of a Single Dose of Voriconazole Administered Orally with and without Food to Red-Tailed Hawks (Buteo jamaicensus). Am. J. Vet. Res. 2017, 78, 433-439. [CrossRef] [PubMed]

215. Azmanis, P.; Pappalardo, L.; Sara, Z.A.J.; Silvanose, C.; Naidoo, V. Pharmacokinetics of Voriconazole after a Single Intramuscular Injection in Large Falcons (Falco Spp.). Med. Mycol. 2020, 58, 661-666. [CrossRef]

216. Souza, M.J.; Redig, P.; Cox, S.K. Plasma Concentrations of Itraconazole, Voriconazole, and Terbinafine When Delivered by an Impregnated, Subcutaneous Implant in Japanese Quail (Coturnix japonica). J. Avian Med. Surg. 2017, 31, 117-122. [CrossRef]

217. Phillips, A.; Fiorello, C.V.; Baden, R.M.; Liu, J.H.; Burmas, N.C.; Ruvalcaba, C.A.; Monroy, R.; Mohr, F.C.; Gehring, R.; Delplanque, J.-P.; et al. Amphotericin B Concentrations in Healthy Mallard Ducks (Anas platyrhynchos) Following a Single Intratracheal Dose of Liposomal Amphotericin B Using an Atomizer. Med. Mycol. 2018, 56, 322-331. [CrossRef]

218. Emery, L.C.; Cox, S.K.; Souza, M.J. Pharmacokinetics of Nebulized Terbinafine in Hispaniolan Amazon Parrots (Amazona ventralis). J. Avian Med. Surg. 2012, 26, 161-166. [CrossRef] [PubMed]

219. Wlaź, P.; Knaga, S.; Kasperek, K.; Wlaź, A.; Poleszak, E.; Jeżewska-Witkowska, G.; Winiarczyk, S.; Wyska, E.; Heinekamp, T.; Rundfeldt, C. Activity and Safety of Inhaled Itraconazole Nanosuspension in a Model Pulmonary Aspergillus fumigatus Infection in Inoculated Young Quails. Mycopathologia 2015, 180, 35-42. [CrossRef]

220. Verweij, P.E.; Lucas, J.A.; Arendrup, M.C.; Bowyer, P.; Brinkmann, A.J.F.; Denning, D.W.; Dyer, P.S.; Fisher, M.C.; Geenen, P.L.; Gisi, U.; et al. The One Health Problem of Azole Resistance in Aspergillus fumigatus: Current Insights and Future Research Agenda. Fungal Biol. Rev. 2020, 34, 202-214. [CrossRef]

221. Beardsley, J.; Halliday, C.L.; Chen, S.C.-A.; Sorrell, T.C. Responding to the Emergence of Antifungal Drug Resistance: Perspectives from the Bench and the Bedside. Future Microbiol. 2018, 13, 1175-1191. [CrossRef] 
222. Melo, A.M.; Stevens, D.A.; Tell, L.A.; Veríssimo, C.; Sabino, R.; Xavier, M.O. Aspergillosis, Avian Species and the One Health Perspective: The Possible Importance of Birds in Azole Resistance. Microorganisms 2020, 8, 2037. [CrossRef]

223. Beernaert, L.A.; Pasmans, F.; Van Waeyenberghe, L.; Dorrestein, G.M.; Verstappen, F.; Vercammen, F.; Haesebrouck, F.; Martel, A. Avian Aspergillus fumigatus Strains Resistant to Both Itraconazole and Voriconazole. Antimicrob. Agents Chemother. 2009, 53, 2199-2201. [CrossRef] [PubMed]

224. Reed, K.; Macgregor, S.K.; Stidworthy, M.F.; Denk, D.; Guthrie, A. The Isolation and Antimicrobial Sensitivity of Aspergillus fumigatus from Frozen Respiratory Tissues of Penguins from Zoological Collections in the United Kingdom, 2007-2018. J. Zoo Wildl. Med. 2020, 51, 591-597. [CrossRef] [PubMed]

225. Ziołkowska, G.; Tokarzewski, S.; Nowakiewicz, A. Drug Resistance of Aspergillus fumigatus Strains Isolated from Flocks of Domestic Geese in Poland. Poult. Sci. 2014, 93, 1106-1112. [CrossRef]

226. Spanamberg, A.; Ravazzolo, A.P.; Denardi, L.B.; Hartz, S.A.; Santurio, J.M.; Driemeier, D.; Ferreiro, L.; Spanamberg, A.; Ravazzolo, A.P.; Denardi, L.B.; et al. Antifungal Susceptibility Profile of Aspergillus fumigatus Isolates from Avian Lungs. Pesqui. Vet. Bras. 2020, 40, 102-106. [CrossRef]

227. Rojo-Solís, C.; García-Párraga, D.; Montesinos, A.; Ardiaca-García, M.; Álvaro, T.; Valls, M.; Barros-García, C.; Encinas, T. Pharmacokinetics of Single Dose Oral Terbinafine in Common Shelducks (Tadorna tadorna). J. Vet. Pharmacol. Ther. 2020. [CrossRef]

228. Bechert, U.; Christensen, J.M.; Poppenga, R.; Le, H.; Wyatt, J.; Schmitt, T. Pharmacokinetics of Orally Administered Terbinafine in African Penguins (Spheniscus demersus) for Potential Treatment of Aspergillosis. J. Zoo Wildl. Med. 2010, 41, 263-274. [CrossRef]

229. Evans, E.E.; Emery, L.C.; Cox, S.K.; Souza, M.J. Pharmacokinetics of Terbinafine after Oral Administration of a Single Dose to Hispaniolan Amazon Parrots (Amazona ventralis). Am. J. Vet. Res. 2013, 74, 835-838. [CrossRef]

230. Zalesak, S.M.; Sanchez, C.R.; Pich, A.A.; Papich, M.G. Preliminary Pilot Study of Itraconazole After a Single Oral Dose of a Veterinary Formulation Solution in African Penguins (Spheniscus demersus). J. Avian Med. Surg. 2020, 34, 52-56. [CrossRef] [PubMed]

231. Sánchez, C.R.; Zalesak, S.; Pich, A.A.; Papich, M.G. Population Pharmacokinetics of Itraconazole Solution after a Single Oral Administration in Captive Lesser Flamingos (Phoeniconaias Minor). J. Vet. Pharmacol. Ther. 2019, 42, 1-6. [CrossRef]

232. Bunting, E.M.; Madi, N.A.; Cox, S.; Martin-Jimenez, T.; Fox, H.; Kollias, G.V. Evaluation of Oral Itraconazole Administration in Captive Humboldt Penguins (Spheniscus humboldti). J. Zoo Wildl. Med. 2009, 40, 508-518. [CrossRef]

233. Pardeike, J.; Weber, S.; Zarfl, H.P.; Pagitz, M.; Zimmer, A. Itraconazole-Loaded Nanostructured Lipid Carriers (NLC) for Pulmonary Treatment of Aspergillosis in Falcons. Eur. J. Pharm. Biopharm. 2016, 108, 269-276. [CrossRef]

234. Schmidt, V.; Demiraj, F.; Di Somma, A.; Bailey, T.; Ungemach, F.R.; Krautwald-Junghanns, M.-E. Plasma Concentrations of Voriconazole in Falcons. Vet. Rec. 2007, 161, 265-268. [CrossRef]

235. Hyatt, M.W.; Wiederhold, N.P.; Hope, W.W.; Stott, K.E. Pharmacokinetics of Orally Administered Voriconazole in African Penguins (Spheniscus demersus) after Single and Multiple Doses. J. Zoo Wildl. Med. 2017, 48, 352-362. [CrossRef]

236. Sanchez-Migallon Guzman, D.; Flammer, K.; Papich, M.G.; Grooters, A.M.; Shaw, S.; Applegate, J.; Tully, T.N. Pharmacokinetics of Voriconazole after Oral Administration of Single and Multiple Doses in Hispaniolan Amazon Parrots (Amazona ventralis). Am. J. Vet. Res. 2010, 71, 460-467. [CrossRef] [PubMed]

237. Gentry, J.; Montgerard, C.; Crandall, E.; Cruz-Espindola, C.; Boothe, D.; Bellah, J. Voriconazole Disposition After Single and Multiple, Oral Doses in Healthy, Adult Red-Tailed Hawks (Buteo jamaicensis). J. Avian Med. Surg. 2014, 28, 201-208. [CrossRef] [PubMed]

238. Kline, Y.; Clemons, K.V.; Woods, L.; Stevens, D.A.; Tell, L.A. Pharmacokinetics of Voriconazole in Adult Mallard Ducks (Anas platyrhynchos). Med. Mycol. 2011, 49, 500-512. [CrossRef] [PubMed]

239. Tell, L.A.; Clemons, K.V.; Kline, Y.; Woods, L.; Kass, P.H.; Martinez, M.; Stevens, D.A. Efficacy of Voriconazole in Japanese Quail (Coturnix japonica) Experimentally Infected with Aspergillus fumigatus. Med. Mycol. 2010, 48, 234-244. [CrossRef]

240. Beernaert, L.A.; Pasmans, F.; Baert, K.; Van Waeyenberghe, L.; Chiers, K.; Haesebrouck, F.; Martel, A. Designing a Treatment Protocol with Voriconazole to Eliminate Aspergillus fumigatus from Experimentally Inoculated Pigeons. Vet. Microbiol. 2009, 139, 393-397. [CrossRef]

241. Mullineaux, E.; Eva, K. BSAVA Manual of Wildlife Casualties; British Small Animal Veterinary Association: Gloucester, UK, 2017.

242. Fox, A.D.; Elmberg, J.; Tombre, I.M.; Hessel, R. Agriculture and Herbivorous Waterfowl: A Review of the Scientific Basis for Improved Management. Biol. Rev. 2017, 92, 854-877. [CrossRef] [PubMed]

243. Nieguitsila, A.; Deville, M.; Jamal, T.; Halos, L.; Berthelemy, M.; Chermette, R.; Latouche, S.; Arné, P.; Guillot, J. Evaluation of Fungal Aerosols Using Temporal Temperature Gradient Electrophoresis (TTGE) and Comparison with Culture. J. Microbiol. Methods 2007, 70, 86-95. [CrossRef]

244. Martony, M.; Nollens, H.; Tucker, M.; Henry, L.; Schmitt, T.; Hernandez, J. Prevalence of and Environmental Factors Associated with Aerosolised Aspergillus Spores at a Zoological Park. Vet. Rec. Open 2019, 6, e000281. [CrossRef]

245. de Wit, J.J.; van Cutsem, J.; Schoenmaker, G.J.; Braunius, W.W.; van den Bergh, J.P. A severe Aspergillus flavus infection in slaughtering chicks and the effect of disinfection with enilconazole: A case study. Tijdschr. Diergeneeskd. 1993, 118, 511-513.

246. Ebani, V.V.; Najar, B.; Bertelloni, F.; Pistelli, L.; Mancianti, F.; Nardoni, S. Chemical Composition and In Vitro Antimicrobial Efficacy of Sixteen Essential Oils against Escherichia Coli and Aspergillus fumigatus Isolated from Poultry. Vet. Sci. $2018,5,62$. [CrossRef] 
247. Redig, P. EasMycotic Infections in Birds I: Aspergillosis. The North American Veterinary Conference Proceedings, Orlando, FL, USA, 17-21 January 2004; pp. 1192-1194.

248. Mazet, J.A.K.; Newman, S.H.; Gilardi, K.V.K.; Tseng, F.S.; Holcomb, J.B.; Jessup, D.A.; Ziccardi, M.H. Advances in Oiled Bird Emergency Medicine and Management. J. Avian Med. Surg. 2002, 16, 146-149. [CrossRef]

249. Feldmesser, M. Prospects of Vaccines for Invasive Aspergillosis. Med. Mycol. 2005, 43, 571-587. [CrossRef] [PubMed]

250. Mateos-Hernández, L.; Risco-Castillo, V.; Torres-Maravilla, E.; Bermúdez-Humarán, L.G.; Alberdi, P.; Hodžić, A.; HernándezJarguin, A.; Rakotobe, S.; Galon, C.; Devillers, E.; et al. Gut Microbiota Abrogates Anti- $\alpha$-Gal IgA Response in Lungs and Protects against Experimental Aspergillus Infection in Poultry. Vaccines 2020, 8, 285. [CrossRef]

251. Wheeler, S.S.; Woods, L.W.; Boyce, W.M.; Eckstrand, C.D.; Langevin, S.A.; Reisen, W.K.; Townsend, A.K. West Nile Virus and Non-West Nile Virus Mortality and Coinfection of American Crows (Corvus brachyrhynchos) in California. Avian Dis. 2014, 58, 255-261. [CrossRef] [PubMed]

252. Hauck, R.; Cray, C.; França, M. Spotlight on Avian Pathology: Aspergillosis. Avian Pathol. 2020, 49, 115-118. [CrossRef] [PubMed]

253. Tsang, C.-C.; Tang, J.Y.M.; Lau, S.K.P.; Woo, P.C.Y. Taxonomy and Evolution of Aspergillus, Penicillium and Talaromyces in the Omics Era-Past, Present and Future. Comput. Struct. Biotechnol. J. 2018, 16, 197-210. [CrossRef] 